\title{
Traditional Patterned Brickwork in New Jersey ${ }^{I}$ \\ By Robert W. Craig
}

\section{DOI: http://dx.doi.org/10.14713/njs.v5i1.169}

This article traces the history of the first architecture of refinement in colonial New Jersey: traditional patterned brickwork, the artful ways in which bricklayers used vitrified bricks to decorate the outer walls of the houses they built. These practices had their roots in $16^{\text {th }}$ century England, where they were employed in fashionable and prestigious architecture, and where they remained the common knowledge of bricklayers a century later during the rebuilding of London after the Great Fire of 1666. With the slump in the building trades that resulted from the rebuilding, Quaker bricklayers and brickmakers joined the migration to the Delaware Valley, where they found the greatest abundance of brick clay in West New Jersey. In the century that followed, Burlington County experienced the largest number of patterned brickwork buildings, while Salem County became home to the second largest number, the greatest variety of patterns, and most of the best examples. The best and best-preserved of its early buildings, the Abel and Mary Nicholson house, has been designated a National Historic Landmark for its patterned brickwork. The rise of the Georgian style of architecture reduced the popularity of patterned brickwork after 1750. After the Revolutionary War, the ascendancy of the Federal style was incompatible with patterned brickwork, and that sealed its eventual disappearance. This article combines an understanding of these buildings as physical artifacts while collectively placing them within the larger narrative of New Jersey's development during the colonial period.

\footnotetext{
${ }^{1}$ This article derives from a slightly abridged version of this author's context statement (Section E) in the "Traditional Patterned Brickwork in New Jersey, ca.1680-ca.1830 Multiple Property Documentation Form” that was prepared for use in the New Jersey and National Registers of Historic Places Program in 2017, and which was approved by the National Park Service in March 2018. The photos included in this article represent a selection of those used in that same document. Readers who seek a still fuller treatment of the subject can look forward to a book by architectural historian Robert Thompson, expected in a few years.
} 
Southern New Jersey is the principal home of traditional patterned brickwork in the United

States. Surveys of American architecture with a regional focus cite or depict examples, ${ }^{2}$ and the scholar who looked most carefully in a comparative way concluded that New Jersey contained more such buildings than the other states combined. ${ }^{3}$ If this conclusion has not yet been firmly established as fact, it has also not yet been contradicted, as the discovered examples in New Jersey have surpassed 375 and move toward 400 buildings, both surviving and disappeared. Their construction began about 1680 , in the earliest years of the West New Jersey ${ }^{4}$ colony, before the first Philadelphians came ashore, and patterned brickwork continued to be practiced, in waning fashion, until the early years of the $19^{\text {th }}$ century when both its possibilities and its popularity yielded to the imperatives of a new style and a new architectural environment.

Today it is hard to capture what patterned brickwork meant to the first generation that built it on these shores. For these almost exclusively Quaker families, it was an architecture of solid

\footnotetext{
${ }^{2}$ Architectural historian Harold D. Eberlein called attention to these buildings in an article, "Early Brick Houses of Salem County, New Jersey," American Architect (formerly American Architect \& Building News), 120 (August 31, 1921): 139-148. Folk cultural treatments and cultural geographies include Thomas Jefferson Wertenbaker, The Founding of American Civilization: The Middle Colonies (New York: Charles Scribner's Sons, 1938; Reprint 1963), esp. Chap. 7: "The Quaker Spirit in Brick and Stone;" Henry Glassie, Pattern in the Material Folk Culture of the Eastern United States (Philadelphia: Univ. of Pennsylvania Press, 1968): 152-153; Gabrielle Lanier and Bernard L. Herman, Everyday Architecture in the Mid-Atlantic (Baltimore: Johns Hopkins Univ. Press, 1997): 97-108.

${ }^{3}$ The original source of the comparison is Paul V. Love, "Patterned Brickwork in the American Colonies," Ph.D. dissertation, Columbia University, 1950, p.i (Preface), et passim, and Appendix A. Although Love failed to find many examples that have occurred in other states (he especially short-changed Pennsylvania), he also enumerated only a minor fraction of the New Jersey examples. Paul Van Derveer Love (1908-1986) was an interesting figure. It is unclear why he was moved to study patterned brickwork houses. Born in Long Branch, New Jersey and raised in the northern part of the state, he taught at a Passaic County high school at the start of his career, in all of which places patterned brickwork buildings are either entirely absent or nearly so. However, he also wrote his master's thesis on patterned brickwork in Salem County, and he married Ora Penton, whose name suggests she was a member of a longstanding Salem County family. Love attended Columbia University for both his M.A. and his doctorate, earning a Ph.D. in art history in 1950. He eventually became a tenured art history professor at Michigan State University, and the University archives holds a substantial collection of his papers. Only in New Jersey, however, is he remembered for his writings on patterned brickwork. After penning an article in 1955 summarizing his dissertation findings for the Proceedings of the New Jersey Historical Society, he seems never to have touched the subject again. Elsewhere, where he is remembered at all, it is for his large body of work on modern dance.

${ }^{4}$ In its earliest years from 1664 to 1676 , New Jersey was a single, proprietary colony. It was divided into two proprietary colonies, West New Jersey and East New Jersey from 1676 to 1702 (hereafter referred to as West Jersey and East Jersey), then was a single, royal colony afterward.
} 
possession, and it was theirs. To a people who had been a small, despised minority in England, hounded and prosecuted for their faith, ${ }^{5}$ these brick houses, even more so than the more numerous frame houses, represented the ability to acquire property and substance that had been denied them at home. Even more broadly, of the several vernacular architectures that spread themselves regionally across the New Jersey landscape before the middle of the $19^{\text {th }}$ century, patterned brickwork was the only one that took its inspiration from a high-style, high-end precedent, an architecture of power and permanence, and it was the only one that symbolized the coming rise of American capability to construct great buildings. It was the first recognizable architecture of "refinement" in New Jersey, one that responded not to those first pioneer conditions but pointed past them toward a more accomplished future. ${ }^{6}$ Flemish checker, the most common pattern, in which the plainly fired long side of a brick (a "stretcher") alternated with a highly reflective, glassy ("vitrified") short end of a brick (a "header"), was an evocation in brick of the weave of linen cloth. $^{7}$ The patterns of vitrified brick were the architectural equivalent of the decoration that adorned that cloth, as when girls stitched golden-colored threads into their samplers, and the dates and initials laid in with brick were like monograms. The golden glow that sunlight produced on the brickwork - and still does ${ }^{8}$ when the viewing conditions are right - gave expression to all the possibilities for a fine future.

\footnotetext{
${ }^{5}$ Perhaps as many as one-third of the adult males in early West Jersey had been jailed in England for reasons related to Quakerism, as well as many Quaker women. For an extensive treatment, see Craig W. Horle, The Quakers and the English Legal System, 1660-1688 (Philadelphia: University of Pennsylvania Press, 1988.) See also David Hackett Fischer, Albion's Seed: Four British Folkways in America (New York: Oxford University Press, 1989), 486.

${ }^{6}$ See for comparison, Richard L. Bushman, The Refinement of America (New York: Vintage Books, 1993).

${ }^{7}$ Cf. to designs in Betty Ring, Girlhood Embroidery: American Samplers and Pictorial Needlework (New York: Alfred A. Knopf, 1993). In Flemish checker, the courses of brickwork also alternate, so that the vitrified headers in one course are centered above the plain stretchers of the course below. It is this combination that yields the checkerboard-like appearance.

${ }^{8}$ When looking at patterned brickwork without the glare of reflected light, vitrified headers most often seem darker in color than the bricks that surround them. They more often appear as black or as a dark, slate gray, or of the color of pewter or lead. But bricklayers could do what alchemists could not: in reflected sunlight, dark headers turn golden for fleeting moments, piece by piece to a viewer up close, seen from the right angle at the right time. For another acknowledgment of these bricks' enduring reflectivity, see Cary Carson and Carl R. Lounsbury, eds. The Chesapeake
} 
Patterned brickwork appeared in perhaps one percent of the houses built in New Jersey in the colonial period, ${ }^{9}$ but as architectural historian Damon Tvaryanas has noted, "they made an architectural statement far disproportionate to their numbers. As a group, they were the largest, most expensive, and most impressive private buildings constructed in West New Jersey, and they visually dominated the landscape of the colony." 10 Patterned brickwork was not spread evenly across that landscape. Although isolated examples appeared even in northern New Jersey locations where the conditions for brick construction were favorable, the overwhelming majority of patterned brickwork - about 95 percent-was built in six southwestern counties, but even where it was most popular it appeared in fewer than one house in six. ${ }^{11}$ Even among the brick houses of early New Jersey, patterned brickwork is in the minority. Yet it had an appeal that has transcended the generations who built these buildings. By the middle of the $19^{\text {th }}$ century, patterned brickwork drew attention for its old-fashionedness, and these buildings were photographed once photography became popular. At least in Salem County, a modest literature has grown up about them. Artists have painted them. ${ }^{12}$ Even builders have repeatedly appropriated the motifs of patterned brickwork during the past two centuries. In the $20^{\text {th }}$ century, brickmaking firms produced bricks with a reflectivity that mimicked vitrified headers, and some builders gave a new rustic expression to Flemish checker. Today, patterned brickwork still comes into and goes out of architectural fashion, and the Internet reveals that patterning is carried out with a greater imagination than ever.

\footnotetext{
House: Architectural Investigation by Colonial Williamsburg (Chapel Hill, NC: University of North Carolina Press and Colonial Williamsburg, 2013), 246.

${ }^{9}$ A similar situation prevailed in Maryland and Delaware, where the incidence of brick architecture was small, though its impact large; see Carson et al, The Chesapeake House, 255.

${ }^{10}$ Damon Tvaryanas, "Parallel or Precedent: Patterned Brickwork Architecture and Quaker Needlework," Folk Art 29, 1-2 (Spring/Summer 2004): 43.

${ }^{11}$ Chiarappa, dissertation, 49, and 60 (note 72).

${ }^{12}$ In Burlington, local artist John Collins painted some early buildings there during the middle $19^{\text {th }}$ century. The Salem County Historical Society holds a collection of paintings of old Salem County houses, painted in the 1880s by local artist and photographer James H. Simkins.
} 
Although most patterned brickwork houses in New Jersey are privately owned, an impressive number are in public stewardship. One $18^{\text {th }}$ century patterned brickwork house is owned and interpreted by the State park system: the William Hancock house in Salem County. Another, the James and Ann Whitall house, is owned and interpreted by Gloucester County. The Burlington County Park System owns the Ezekiel Wright house at Smithville. The Mercer County Park System owns the shell that was the John Rogers house, with plans to stabilize and interpret it. Five county historical societies own, occupy, or have their headquarters in patterned brickwork houses. The New Jersey chapter of the Society of the Colonial Dames of America owns and interprets the Old Schoolhouse in Mount Holly. Patterned brickwork was a theme highlighted by the National Park Service in its New Jersey Coastal Heritage Trail. The William Trent House, Trenton's house museum, occupies the capital city's finest patterned brickwork house. The White

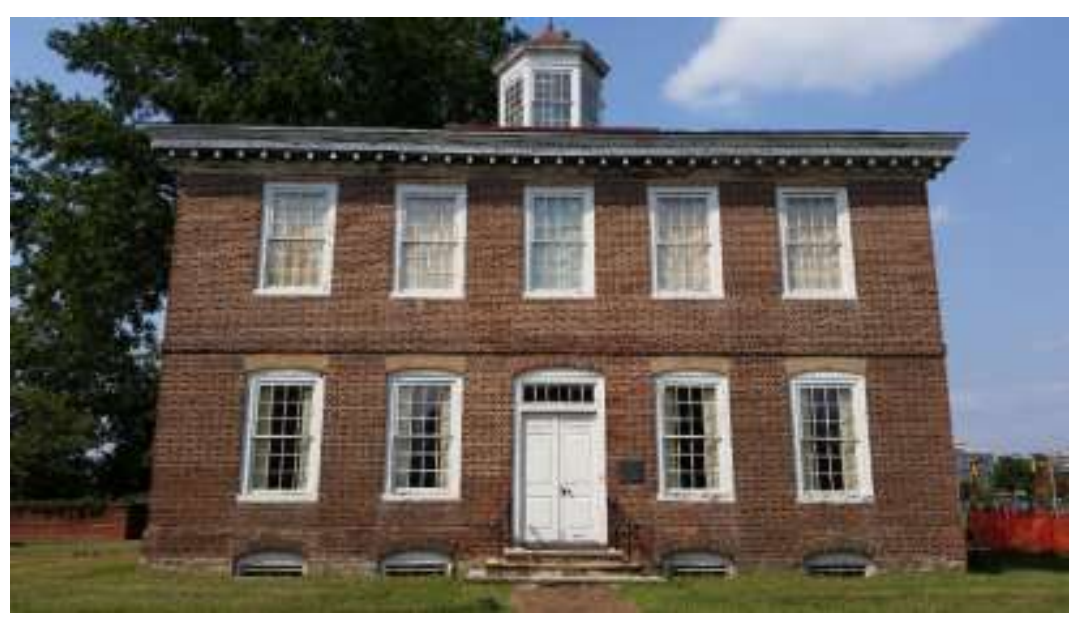

The William Trent House, Trenton, NJ, National Historic Landmark. Photograph by the author.
Hill mansion in Fieldsboro has been acquired by the Borough of Fieldsboro, which is researching and repairing it. The Joseph Brearley house in Lawrence Township is township-owned, as is the Isaac Pearson house in Hamilton Township.

The patterned-brickwork houses of New Jersey collectively comprise a national architectural treasure. Vernacular architecture and folklife historian Michael Chiarappa called these buildings among "West [New] Jersey's most powerful and meaningful artifacts." 13 The best

\footnotetext{
${ }^{13}$ Michael J. Chiarappa, "The Social Context of Eighteenth-Century West Jersey Brick Artisanry," Perspectives in Vernacular Architecture IV (Columbia, MO; and London: University of Missouri Press, 1991), 31.
} 
of the early examples, the Abel and Mary Nicholson house (1722), has been designated a National Historic Landmark. ${ }^{14}$ About 75 New Jersey patterned brickwork buildings have been recorded with measured drawings and photographs by the Historic American Buildings Survey (HABS), and more than 80 have been listed in the National Register of Historic Places (not all the same ones). Despite all of the attention they have received, many worthy buildings that meet the eligibility requirements, including some quite important ones, remain unlisted in the New Jersey and National registers. These buildings represent English craft influence, Quaker-led innovation, and American prosperity across the span of the $18^{\text {th }}$ century. Brick was an expensive material wherever it appeared in colonial America, and New Jersey did not have a monopoly on its use, but only in southern New Jersey - the old colony of West Jersey_and subsequently in Philadelphia did brick tradesmen appear with the first English arrivals and so prominently contribute to its architectural history from the very beginning.

\section{Defining "Patterned Brickwork"}

In this document, the phrase "patterned brickwork" means the deliberate use by a bricklayer of "vitrified" brick (brick as if glazed) or at least darkened brick to form patterns in a wall based on the contrasting color and reflectivity of the bricks. It is thus meant to differ from ordinary or plain brickwork which did not take advantage of these qualities. Ordinary brickwork employed the same bonds-English, Flemish, and common bond-but executed them in the common range of reddish colors found in plain, common brick. Both classes of brickwork employed the same bricks, but masons laying ordinary brickwork did not use the vitrified bricks for any decorative purpose.

\footnotetext{
14 Two other New Jersey patterned brickwork houses have also been designated NHLs, for historic figures associated with them: the Francis Hopkinson house (1730), in Burlington County, and the William Trent house, built 1719-21 in Mercer County. In Gloucester County, the Red Bank battlefield, which contains the James and Ann Whitall house (1748), has been designated a NHL.
} 
Patterned brickwork in America was almost exclusively a two-dimensional art. Sophisticated three-dimensional modeling of brick clay, which in some famous English buildings resulted in Gothic tracery or elaborate chimney tops being executed in brick, was not carried out in New Jersey. Apart from water table bricks, which were molded with either a Roman ovolo or were beveled, sculptural effects were rarely attempted, and never on a large scale. ${ }^{15}$ Thus the work of the brickmakers was not a significant factor in this architectural fashion; patterned brickwork was the art of the bricklayer. ${ }^{16}$

\section{Patterned Brickwork in England}

The direct roots of New Jersey's patterned brickwork lie in England. ${ }^{17}$ Although efforts to find that influence elsewhere have been made with unconvincing results, ${ }^{18}$ the evidence for a direct

\footnotetext{
${ }^{15}$ There are a few examples of date plaques that embodied a tiny amount of three-dimensional modeling; for one example see Bernard Herman, "Eighteenth-Century Quaker Houses ...," in Emma J. Lapsansky et al., Quaker Aesthetics: Reflections on a Quaker Ethic in American Design and Consumption (Philadelphia: University of Pennsylvania Press, 2003) 188-211.

${ }^{16}$ The particular phrase, "patterned brickwork," has been deliberately chosen to emphasize the role of bricklayers in this architectural phenomenon. It is not the fabrication of individual bricks that embodied patterning (except insofar as they were modified by the bricklayer), but rather in the manner in which they were assembled. Alternative possibilities such as "pattern brick," "pattern brickwork," etc. were rejected for this reason. This choice is not novel. "Patterned brickwork" was also the phrase that Paul Love chose in his writings. Damon Tvaryanas chose it for his 2004 article in the journal Folk Art. It is the usage chosen for the Old-House Dictionary, and it is the usage adopted by this writer in a brief earlier treatment of New Jersey's patterned brickwork. See Stephen J. Phillips, The Old-House Dictionary: An Illustrated Guide to American Domestic Architecture 1600 to 1840 (New York: John Wiley \& Sons, 1994); Damon Tvaryanas, "Parallel or Precedent: Patterned Brickwork Architecture and Quaker Needlework," Folk Art 29, 1-2 (Spring/Summer 2004), 42-53; Robert W. Craig, "Patterned Brickwork," Encyclopedia of New Jersey (New Brunswick, NJ: Rutgers Univ. Press, 2004): 620. It also represents a compromise between George W. Johnson's "patterned brick" and Michael Chiarappa's "pattern brickwork."

${ }^{17}$ The classic work on English brickwork is Nathaniel Lloyd, A History of English Brickwork, With Examples and Notes of the Architectural Use and Manipulation of Brick from Medieval Times to the End of the Georgian Period (London: [H.] Grenville Montgomery, 1925; New York: W. Helburn, Inc., 1925). More recent scholarship includes Ronald W. Brunskill and Alec Clifton-Taylor, English Brickwork (London: A Hyperion Book, Ward Lock Limited, 1977 [hereafter "Brunskill"]); and Peter Guillery, The Small House in Eighteenth-Century London: A Social and Architectural History (New Haven and London: Yale University Press, 2004). For London architecture, the many volumes of the Survey of London, published jointly by the London County Council and the London Survey Committee since 1900, are the foundation for any architectural study of that city.

${ }^{18}$ Allen Gowans argued for a Swedish-influenced origin to Delaware Valley patterned brickwork in "The Mansions of Alloways Creek," upon the basis of weak and conflicting evidence. Curiously, he carried on this argument in the notes of his article, rather than the text. He dismissed a direct English precedent for Delaware Valley patterned brickwork, believing that English patterned brickwork ceased in the $16^{\text {th }}$ century, ignoring that it survived in English vernacular building construction for another two centuries (see text below). Architectural historian Damon Tvaryanas also failed to find Gowans' argument convincing. Folk Art (Spring/Summer 2004): 44.
} 
borrowing from London and southeastern England is, in this author's opinion, direct, compelling, and unassailable. Even the Swedish minister Israel Acrelius, who in 1758 wrote an account of the Swedish churches in the Delaware Valley, stated "the houses along the Delaware are built of bricks, after the English fashion, every other brick glazed." ${ }^{19}$ The influences upon English brickwork, however, were Continental. Among the countries of Europe, the use of brick in architecture came late to England. ${ }^{20}$ For the type of English patterned brickwork that would later be practiced in the American colonies, he argues for a French connection. ${ }^{21}$ The English word brick derives in the $15^{\text {th }}$ century from the French word brique, according to both Lloyd and Brunskill, but more tellingly, Lloyd explains, a French influence "that caused brickmaking and building in brick to be carried out in localities more widely apart" than had previously been the case. Lloyd continued,

The strongest evidences in support of [the] theory of French influence are the facts (i) that certain fifteenth-century brick castles were built by English knights and peers, who had been engaged in wars against France, and had even established themselves in French castles for years, from which they organized raids and despoiled that country; (ii) that what we term 'English bond,' which was in use in France, became adopted generally in England in place of the irregular bond of early medieval work, and (iii) the introduction of diaper patterns on wall surfaces formed by flared headers of dark colour and partially vitrified." 22

Paul Love agreed with this interpretation, and further observed that French influence was limited to English patterned brickwork, but had no direct influence on American colonial brickwork. He could find no examples of patterned brickwork in France's American colonies. ${ }^{23}$

\footnotetext{
${ }^{19}$ Quoted in Gowans, 389, footnote 1.

${ }^{20}$ Lloyd, History of English Brickwork, 1-7.

${ }^{21}$ Ibid., 7-8.

${ }^{22}$ Ibid., 7.

${ }^{23}$ Love, dissertation, 10. There was likewise no patterned brickwork in the areas of northern New Jersey where French Huguenots early settled, though those were areas where stone was widely available and extensively used. Curiously, these areas would develop a type of patterned stonework employing brownstone that was practiced during a period roughly contemporary with traditional patterned brickwork, and in some cases imitated diapering effects.
} 
A principal reason that some architectural historians have not embraced a view that the patterned brickwork of the Delaware Valley is fundamentally English in origin is a supposed 200year gap between the use of patterned brickwork in such prominent buildings as Hampton Court (in the 1520s) and the heyday of patterned brickwork in the Delaware Valley in the middle 1700s. Gowans wrote of a "two-century hiatus." 24 Certainly the plates published in Lloyd argue for the proposition that patterned brickwork disappeared from British high architecture before the end of the $16^{\text {th }}$ century. Yet there was no hiatus. "It should be remembered," Love wrote, "that patterned brickwork was in full stride ... in the 17th century for minor buildings in England; [and] that it was [part of the] common knowledge of the builder and bricklayer in England." Patterned brickwork survived in vernacular architecture in the parts of England where brick was produced and used, chiefly in the counties to the south and east of London, and in London itself.

\section{The Great Fire of London and its Aftermath}

On September 2, 1666, the combustion ever afterward known as the Great Fire of London broke out uncontrollably in one of the poorer sections of that largely timber-framed city. In three days of frantic confusion, more than 13,000 buildings burned, about 85 percent of the old city within the ancient walls. Before the Fire, the land outside the walls could still largely be characterized as open fields, and it was there to which most of the dispossessed from the fire evidently went. ${ }^{25}$ The year after the fire was largely consumed with the legal, financial, and logistical preparations for rebuilding. A Parliamentary statute of 1667 determined that the city would be rebuilt in brick and stone. It was the spring of 1668 before reconstruction activity was

\footnotetext{
${ }^{24}$ Gowans, "The Mansions of Alloways Creek," 389-391.

25 This treatment is largely taken from T.F. Reddaway, Rebuilding London after the Great Fire (London: Edward Arnold \& Co., 1940). Largely agreeing with his conclusions but taking a different approach to the subject is Elizabeth Kelleher, The Birth of Modern London: The Development and Design of the City, 1660-1720 (Manchester, UK and New York: Manchester University Press, 1999).
} 
generally underway. For the first few years afterward, London experienced a construction boom that brought many journeymen into the city from distant counties, including masons and bricklayers. In the early 1670s, however, hard times set in as the rebuilding of the city got too far ahead of the effective demand for housing. Nearly all rebuilding of houses was complete by the end of $1672 .{ }^{26}$ But what had been open spaces around the city before the Fire had become suburbs of it - the word suburb was actually used — and many former city residents were either unwilling or unable to return to the old city as it rebuilt. After the city conducted a population census in 1673, "the problem of empty houses replaced that of empty spaces, and pride in the achievement of rebuilding gave way to anxiety about re-peopling.,"27

\section{The Making of Vitrified Brick}

The authors of building trade manuals who wrote during the heyday of English patterned brickwork included Stephen Primatt, William Leybourne, John Houghton, and Richard Neve. Their careers overlapped, but the names can be thought of as in roughly chronological order, based on their most important writings. Leybourne wrote in 1684 that brickmakers would select clays "that will vitrifie," or become like glass. ${ }^{28}$ He wrote that some tradesmen called bricks possessing this attribute "clinkers," and he classified such bricks as being of "the first and best sort." 29 Stephen Primatt wrote that this sort of brick made a "tinckling" sound when one was struck with another. ${ }^{30}$ Leybourne further explained that "those which in burning lie next to the fire in the keele [sic], which, if they have much salt-peter in them, they will run and be as it were glazed all over."

By this Leybourne was explaining that the firing would fuse the ends of brick directly exposed to

\footnotetext{
${ }^{26}$ Stephen Inwood, History of London, (New York: Carroll \& Graf, 1999), 244-249.

${ }^{27}$ Reddaway, 302.

${ }^{28}$ William Leybourne, The Builder's Guide (London: 1684): Book 2, p.129; quoted in Love, dissertation, p.1.

${ }^{29}$ William Leybourne, A Platform for Purchasers, Guide for Builders, Mate for Measurers (London: Thomas Radcliffe and Thomas Daniel, 1668; $2^{\text {nd }}$ edition, 1685); 129.

${ }^{30}$ Stephen Primatt, The City and Country Purchaser... second edition much enlarged by William Leybourne (London: John Wright, 1667) 51.
} 
the fire into hard, tinted, and glossy finishes, ie. "glazed," though no substance that any potter would understand to be a glaze was ever applied.

Writers other than Leybourne did not have such a high opinion of clinkers, nor did they describe them in the same terms. John Houghton, a writer who described brickmaking in 1693 had a decidedly more negative opinion of these bricks and their makers. Houghton wrote that poorly-trained brickmakers who did not alternately fire the clamp and then slack the fire several times, thereby to help even out the temperature within, made the raw brick in the lower part of the clamp "run so with the excessive Heat, that they are almost united in one entire Body; so that they are forced to get them out with ... Iron bars." 31 Brick burned in that manner would have been unusable for any decorative purpose. He seemed to associate this problem with a primitive form of clamp more susceptible of this result.

However, Houghton also described a very different form of clamp, apparently a larger and more efficient kind, composed of "arches," in which the raw bricks were stacked mostly in "long necks," 42 bricks long, or in "short neck[s], which [are] about 30 bricks long." 32 The raw bricks were stacked up to a height of about three feet, then subsequent bricks were corbeled over the brick below to close the arch. Raw bricks were then stacked upon them to the height of several additional feet, enough that where long necks were used, each arch accounted for ten thousand bricks. ${ }^{33}$ While one might question whether brickmaking practices described in these manuals were actually followed in the Delaware Valley, when the Chesterfield Monthly Meeting of Friends built its meetinghouse in 1707 , its brick was evidently shipped in loads of ten thousand. ${ }^{34}$

\footnotetext{
${ }^{31}$ Neve, City and Country Purchaser ... (1726 edition), [unpaginated, "Brick" entry]. The parentheses are as in the original.

${ }^{32}$ John Houghton, A Collection for Improvement of Husbandry and Trade, no.73, December 22, 1693, p.195.

33 Ibid.

${ }^{34}$ RG2, Ph/C47/6.4, Friends Historical Library, Swarthmore College, Swarthmore, PA.
} 
It may be that this form of clamp became commonly used by Delaware Valley brickmakers. Clamps fashioned in this manner would produce many bricks - the corbeled ones - that would have not only one end that would "run" or vitrify, but also a minor portion of the adjacent bedding plane. In the buildings of the Delaware Valley it is commonplace to see bricks with such resulting surfaces, which means they must have been stacked in arch-fashion, and that they "ran" not because they were on the bottom, but because they were corbeled over one another in the arch and directly exposed to the heat, however well-controlled the temperature may have been. Only clinkers that were well-formed could be used in the exteriors of buildings, but this type of clamp would have produced many such bricks, given the right ingredients to begin with, and skillful hands attending the fire. Evidently bricks that lacked the substances that would cause vitrification merely darkened in the firing.

How many vitrified bricks such a clamp would yield may have affected how extensively patterned brickwork was executed in New Jersey. From straightforward arithmetic, in the design of an arch-type clamp described by Houghton, about 1,500 to 2,000 bricks would have been directly exposed to the heat of the flame for each arch of 10,000 bricks, or about one brick in six. These bricks would have ranged from the bottom of the clamp to the middle, but with a homogeneous mixture of the clay and proper firing and slacking, all or nearly all exposed to the fire could be expected to darken or vitrify alike. For a wall laid in Flemish checker, if that wall were one foot thick (1.5 bricks thick), then two bricks of every nine would need to be vitrified on one end, or 22 percent. In a wall of only one brick thickness, four vitrified headers would be needed for each 12 bricks, or 33 percent. In either case, a wall so laid would require a greater percentage of vitrified headers than the clamp would produce, which, in turn, would limit the number of elevations that could be outfitted with that pattern. This may perhaps explain why so 
few examples in New Jersey have more than the facade laid in Flemish checker, and why patterned brickwork seldom appeared below the water table course. (The builder of the William Montgomerie house in Upper Freehold evidently underestimated his needs and ran out of vitrified brick while laying the second-story walls. He could have saved some of the product by dispensing with the stringcourse that he laid with vitrified headers between the first and second stories, suggesting that it was only after that point that he discovered how insufficient his supply was. He did not waste any on secondary elevations, but even without the stringcourse he would not have had enough for the façade.)

The key to whether brick would vitrify at all evidently lay in the composition of the substance to be fired. The authors agreed that the substances from which brick were formed included much more than the "earth" (they avoided the term clay) that was its principal ingredient. Also crucial was the "spanish" (their term) that was added. This was a nasty witches' brew that Houghton wrote consisted largely of coal ashes, street sweepings, and household dust. ${ }^{35} \mathrm{He}$ implied that the substance making "the bricks run" was horse dung, a common component of street sweepings. Houghton wrote, "if horse dung happens to be mixt with any earth, 'twill make the bricks run, and look of a green glazy colour..."36 It is possible even today in the Delaware Valley to find tinges of green in the vitrification of some brick (see "A Spectrum of Colors"). This "spanish" would be sifted and thoroughly mixed with the earth in the autumn, allowed to set all winter, and molded and burnt into brick in the spring.

Richard Neve, writing in the 1720s, agreed that brickmakers never applied glazes to their product, ${ }^{37}$ but the idea of one day doing so was something he actually pondered. He speculated in

\footnotetext{
${ }^{35}$ Houghton, 192.

${ }^{36}$ Ibid., 197.

${ }^{37}$ Although it has become a consensus understanding that glazes were not applied to brick before firing, Michael Chiarappa challenged this view in his 1993 dissertation. While he did not deny that vitrified brick in fact existed, he
} 
terms that made him more than a century ahead of his time when he wrote that if brickmakers would only invest part of their efforts over a period of years, they would, with careful study, eventually find practical, efficient methods to produce brick in a range of beautiful colors, as well as achieving marbling and other desirable effects. But he was resigned to the fact that that would not happen in his lifetime. Alas, he wrote, "But (more is the Pity)-Men of this Profession [brickmaking] are like the Materials they work upon, viz. heavy and lumpish."38

\section{Patterned Brickwork in the early American Colonies}

Paul Love identified that patterned brickwork in colonial America was limited to the eastern seaboard, from New England to North Carolina. ${ }^{39}$ He wrote, "The greatest concentration is in Salem and Burlington counties in southern New Jersey. This state acts as a center outside which, to the north and south, the examples diminish in number, although the South has in all cases more than the North." Love relied heavily on HABS data, and there is bias in his work, both in

nevertheless asserted that "many of the bricks used in West Jersey pattern[ed] brickwork received a glaze finish prior to firing" (Chiarappa, pp.93-94). His statement oddly conflicts both with the British writers cited in this document and with the weight he places on Leybourne, who wrote instead that bricklayers sought out clays "that would vitrifie." Leybourne wrote that the presence of salt-petre within the body of the clay, itself - not applied to its face-would make the brick vitrify. Chiarappa reported a Neve comment about the possibility of using a glaze, but not his comment that English brickmakers did not do so. He also ignored Neve's conclusion that a deliberate research and development program would have been required to obtain practical and effective glazes that could transform brickmaking. English brickmakers throughout the $18^{\text {th }}$ century made bricks with similar uniformity of color and in the same colors that brickmakers produced in the Delaware Valley. That uniformity of result can be accounted for by the quality of the pugging, or mixing of the clay prior to molding. Both Leybourne and Neve agreed that clinkers resulted from nearly every firing, but they disagreed about the definition. To Neve, clinkers were defective brick of little value; to Leybourne they were "the first and best sort;" the finest brick and of unsurpassed durability, which would have been wasted if not used in exterior walls. Chiarappa presents no documentary evidence that brickmakers in the Delaware Valley (or in England) bought glazes or the ingredients for glazes, nor of customers ordering specific colors. Circumstances run solidly against Chiarappa's conjecture. There could have been no widespread use of such bricks in the Delaware Valley. Were it otherwise, there would have appeared many mistakes in the bricklaying, as for example the unintended use of wrong colors in buildings, or the deliberate use of multiple colors in the same building or in the same design, which does not appear in the Delaware Valley. If glazes had been applied to bricks, one could expect a wider variety of colors and much more vivid tones. Instead, the varieties of color are subtle variations on a dark theme (see "A Spectrum of Color"). If glazes had been applied, the sloppiness inherent in such an activity would have left brush marks that have not been found. Where vitrification does extend beyond the header onto the bedding plane (a very common occurrence), it does so predictably and stops abruptly, corresponding to the spacing by which the brick would have most likely been corbeled in the arch-type clamp. This, too, is inconsistent with any possible system of glaze application.

${ }^{38}$ Neve, City and Country Purchaser ... (1726 edition), "Brick" entry, n.p.

${ }^{39}$ Love cites two individual exceptions, one in Kentucky, the other in Louisiana. 
that New Jersey had a more extensive HABS program than other states did, ${ }^{40}$ and that Love had studied the Salem County houses more intensively than any others, but his general conclusion about the distribution of patterned brickwork still seems valid, even if his numbers seem small everywhere.

Of known examples, there are at least three and probably more in Connecticut, at least four in New York, four in Pennsylvania, one hundred and eight in southern New Jersey and one in northern New Jersey, at least six in Delaware, thirty-one in Maryland, fifteen in Virginia, eleven in North Carolina, one in Kentucky, and one in Louisiana. In these totals are not included the many examples of the commonest form of patterned brickwork used alone, the Flemish checker. ${ }^{41}$ [emphasis added]

Love also concluded that, while there may have been some Dutch influence upon the patterned brickwork in New York, the patterned brickwork of New Jersey and to the southward was Englishinfluenced and that in some areas of the South a direct influence from Philadelphia or New Jersey was probable. ${ }^{42}$

\section{The Quaker Impact: Patterned Brickwork in the Delaware Valley}

During the years between 1675 and 1690, about 10,000 members of the Society of Friends emigrated to the Delaware Valley, mostly from England and Ireland, overwhelming a European population (British, Scandinavian, and Dutch) of fewer than $1,000,{ }^{43}$ producing a situation that had no parallel in England: the opportunity (as the Puritans had experienced in New England) for one religious or cultural group to put its stamp on the building construction of an entire region within the American colonies. Historians of vernacular architecture in Britain have not explained what

\footnotetext{
${ }^{40}$ Historic American Buildings Survey, comp. Historic American Buildings Survey: Catalog of the Measured Drawings and Photographs of the Survey in the Collections of the Library of Congress, March 1, 1941 (Washington, DC: United States Government Printing Office, 1941). New Jersey boasted by far the longest series of entries.

${ }^{41}$ Love, dissertation, 4. A few specimens of patterned brickwork have also been found, for example, in Vermont. See Herbert Wheaton Congdon, Old Vermont Houses (Dublin, NH: William L. Baun, 1973).

${ }^{42}$ Love, dissertation, 133, 137. Love's point about a Delaware Valley influence on some areas of the upper South is consistent with the findings of architectural historian Roger Moss, who studied the Philadelphia building trades in the colonial period; see Roger W. Moss, "The Master Builders: A History of the Colonial Philadelphia Building Trades," Ph.D. dissertation, University of Delaware, 1972.

${ }^{43}$ And a Native American population of a few thousands, but uncounted.
} 
motivated clients to employ patterned brickwork in their buildings. One looks in vain through the volumes of the British journal Vernacular Architecture for any treatment of this issue. Clearly, patterned brickwork was widely available in the English context; it could not in Britain have been the exclusive possession of any specific social group. In the American colonies, however, the situation was far different. Quakers brought many building preferences and practices to the Delaware Valley, but patterned brickwork made their buildings more regionally distinctive than did any of their other building practices.

Despite the presence of about one thousand Europeans whose presence predated the Quaker arrivals, it was left to the Quakers to organize the region, to give it its first effective settlement. Swedish, Finnish, and Dutch enclaves in the Delaware Valley had never coalesced into anything that could fully be considered a colony, let alone organize the territory or govern it with staying power. Simply put, they were too few to occupy the region, as their leaders had frequently cautioned their superiors back home. ${ }^{44}$ The Quaker influx completely changed matters. In southern New Jersey, evidence of Swedish or Finnish or Dutch settlement is sparse, while echoes of the early Quaker presence are nearly ubiquitous. Being effectively the first gave Friends the opportunity to place a Quaker stamp on the emerging cultural landscape. Quakers quickly dominated the landholding in West New Jersey, and within a fifteen-year period occupied the coastal plain areas from below Greenwich on the Cohansey River to the site of Trenton on the Assunpink Creek. Among the groups that formed the West New Jersey colony, the Quakers ranked first, in the sense of foremost.

Chiarappa has pointed out that brickwork was "the best sort" of architecture that the Quakers built. It was the finest and most expensive way to build to which a wide range of people

\footnotetext{
${ }^{44}$ Cf. Amandus Johnson, Swedes on the Delaware (Philadelphia: 1927).
} 
could aspire. Patterned brickwork accentuated this characteristic. Patterns highlighted and strengthened the refinement that the presence of brick implied, and made the work still more expensive. The English practice had been to value ordinary bricklaying by the "rod" -4500 bricks - but designs were charged separately, at a higher, negotiated rate (see below). The Quakers did not re-invent traditional English patterned brickwork; they simply brought English brick masonry practices with them. The importance of Quakers to the practice of patterned brickwork lay in the social realm.

While timber-frame houses built according to English framing practices sufficed for most Quaker families, those who wished to own a brick home could build within a range, according to their means. There were small houses built on a "hall" plan, such as the Abbott house in Elsinboro, built in 1704, and the John Rogers house (1718) near Burlington (about which, read more below). Larger homes corresponded to families of greater means, in the most fortunate cases, families whose fortunes were lifted by commercial trading. Both in a spiritual and in a socio-economic sense, patterned brickwork came to be associated with what Quaker historians have identified as "Weighty Friends," a term that was current in the $18^{\text {th }}$ century.

The most important of the brick tradesmen themselves, the master bricklayers and brickmakers, were themselves weighty Friends, judging from the records of the Quakers' monthly meetings. ${ }^{45}$ Chiarappa observed that brick tradesmen "were key actors ... as they built a minority number of structures for a minority of power-wielding members of this religious group. ${ }^{46} \mathrm{He}$ further commented that

\footnotetext{
45 Michael J. Chiarappa, “The Social Context of Eighteenth-Century West New Jersey Brick Artisanry,” 31-43, in Perspectives in Vernacular Architecture IV (Columbia, MO and London: University of Missouri Press, 1991); and “"The First and Best Sort:' Quakerism, Brick Artisanry, and the Vernacular Aesthetics of Eighteenth-Century West New Jersey Pattern Brickwork Architecture.” Ph.D. dissertation, University of Pennsylvania, 1993. pp. 42-48.

46 Ibid., 48.
} 
Under the aegis of the Society of Friends, pattern[ed] brickwork owners and brick [tradesmen] traveled together, fraternized together, and administered together. The exercise of craft patronage made for the simultaneous wielding of social, economic, and political influence on the part of both client and artisan. [Together], ... these [tradesmen] powerfully negotiated the most salient material expressions of the social order. ${ }^{47}$

The sharp geographic focus of patterned brickwork in New Jersey, limiting it almost exclusively to Quaker-settled areas, is also due to further practices that the Friends promoted. They emphasized that their members wherever practical to socialize only with Friends, and to buy from fellow Quakers. ${ }^{48}$ They also encouraged parents to consider their children as "tender plants," and as their sons grew to apprentice them to Quaker masters. In all these ways Friends meetings encouraged and reinforced a series of practices that limited opportunities to spread patterned brickwork beyond the territorial geography dominated by the Friends. ${ }^{49}$

\section{Bringing Brickmaking to a Quaker Colony}

The depressed conditions for construction workers in London after 1672 meant that the leaders of West New Jersey and of Pennsylvania would have no difficulty recruiting building tradesmen to emigrate across the Atlantic. Efforts undertaken during the past several decades have identified dozens of bricklayers and brickmakers who worked in Philadelphia or in West New Jersey before the year 1700, some men working in both colonies. The masonry tradesmen who arrived in the Delaware Valley quickly found that conditions were, indeed, very favorable for brick construction. They may not have been expecting what they would find, however, since the earliest promotional literature that described the Delaware Valley emphasized the flora and fauna and the

\footnotetext{
47 Ibid., 48-49.

${ }^{48}$ See, Frederick Tolles, Meeting House and Counting House (Chapel Hill, NC: University of North Carolina Press, 1948), 89, for a discussion of the Quaker practice of "keeping their Trade within themselves."

${ }^{49}$ Ibid., esp. chapters 2 and 4.
} 
promise of the soil for farming, not its more elusive geological aspects. ${ }^{50}$ The Inner Coastal Plain in southeastern New Jersey and stretching through parts of southeastern Pennsylvania, northern Delaware, and through Kent County, Maryland was well-endowed with clays of a superior quality for brickmaking. ${ }^{51}$ The Delaware Bay also possessed a vast superabundance of oysters, which became a very popular food among all classes of the population. The leftover shells were a ready source of the calcium needed for lime mortar. New Jersey was more favorably situated relative to this wealth of clay than Pennsylvania was, for building stone was widely available through Bucks County, Pennsylvania, and in areas where stone was widely available, good clay often was not, and brick construction was generally not practiced. ${ }^{52}$ This helps explain the relatively small area in which patterned brickwork is found in Pennsylvania compared to southern New Jersey. Patterned brickwork tended to appear wherever suitable clay, brick tradesmen, and a preference for masonry construction combined. The mid-Atlantic inner coastal plain provided many such places, southwestern New Jersey foremost among them.

The population of West New Jersey would have doubtless risen faster were it not for the emergence of Pennsylvania close on its heels. The consensus view has been that the stream of Quaker emigrants to West New Jersey stopped promptly after emigration to Pennsylvania began in $1681,{ }^{53}$ and while such a conclusion is generally true it does not take into account a large but

\footnotetext{
${ }^{50}$ Harry B. Weiss and Grace M. Weiss, The Early Promotional Literature of New Jersey (Trenton, NJ: NJ Agricultural Society, 1964). In 1685, however, after several brick tradesmen had already made their homes in West Jersey and after brick masonry was a widespread activity, Thomas Budd published the fact of the area's abundant brick clays; see Chiarappa, dissertation, 64.

${ }^{51}$ See, for example, the observation made by Thomas Jefferson Wertenbaker, about the line from central New Jersey to Wilmington, Delaware that generally separated the areas of stone and brick construction. Wertenbaker, The Founding of American Civilization: The Middle Colonies, 236. The wide variety of clays in the Inner Coastal Plain were the subject of a one-volume study in 1904: Heinrich Ries and Henry B. Kummel, assisted by George Knapp, The Clays and Clay Industry of New Jersey (vol. 6 of Final Report to the State Geologist), Trenton, NJ: MacCrellish \& Quigley, 1904).

${ }^{52}$ Lloyd, History of English Brickwork, 9, made a similar comment about England.

${ }^{53}$ For an account of the settlement of West Jersey from a political perspective, see John E. Pomfret, The Province of West New Jersey, 1609-1702 (Princeton, NJ: Princeton University Press, 1956). To examine it in its cultural geography dimensions, see Peter O. Wacker, Land and People: A Cultural Geography of Pre-Industrial New Jersey
} 
unestimated number of arrivals at Philadelphia who thereafter settled in West New Jersey. One such man, William Watson (not a building tradesman), left a brief account of his transatlantic crossing in the summer of 1684 that seems representative of the experience of many. Once the ship Bristol Merchant on which he sailed left Bristol, England, the captain drove his passengers to "ffiladefia" in about eight weeks. Only weeks later Watson and his family moved to what soon afterward became Nottingham Township in Burlington County, West New Jersey, where they began to occupy a tract of land that they named for the farm they left behind in Nottinghamshire. ${ }^{54}$

The ability of southern New Jersey clients to sponsor brick construction was somewhat enhanced by the knowledge that an even larger body of brick tradesmen lay just across the river in Philadelphia. With its rapid pace of settlement, Philadelphia's population would seem to have been about 6,000 to 8,000 by the year 1700 , by which time the West Jersey population has been estimated at $4,000 .{ }^{55}$ The respective populations of brick tradesmen in the two colonies were probably rather proportional to these general figures, with a small additional nod to Philadelphia. Philadelphia served as a magnet that drew building tradesmen to it. With the large brick production in Philadelphia, its brickmakers could be relied upon to provide additional brick when required. In at least a few instances, documentation has survived of buildings constructed from brick floated

(New Brunswick, NJ: Rutgers University Press, 1975). For a historic and folklife treatment of the entire Quaker migration to the Delaware Valley, see David Hackett Fischer, Albion's Seed: Four British Folkways in America (New York: Oxford University Press, 1989).

${ }^{54}$ William Watson's ms. book, 1675-[1684]. MG 698, Historical Society of Pennsylvania, Philadelphia, PA. The text uses the word "driven."

55 Philadelphia population estimates for the year 1700 seen by this author vary from 4,400, which seems too low, to 10,000, which seems unrealistically high and in conflict with later, lower estimates. An estimate of 7,000, more or less, would seem more realistic, if Fischer's estimate for the colony of Pennsylvania, at 18,000, is accurate. See Fischer, Albion's Seed, 421, where he also estimated the 1700 population for West Jersey at 4,000. Fischer's West Jersey estimate seems to this author more accurate than the slightly lower number arrived at by Peter O. Wacker, at about 3,300, which was largely based on a 1699 enumeration of freeholders. Cf. Wacker, Land and People: A Cultural Geography of Pre-Industrial New Jersey (New Brunswick, NJ: Rutgers University Press, 1975): 133. 
up the Delaware River (likely from Philadelphia) to a landing near the job site. Likewise, some New Jersey brick production may have been intended for use in Philadelphia. ${ }^{56}$

These circumstances suggest that Philadelphia was the only place in the Delaware Valley in which the number of patterned brickwork buildings rivaled, and may for a time have exceeded, those of New Jersey. ${ }^{57}$ The emphasis on, and incidence of, brick construction in Philadelphia was much greater than in West Jersey, for Philadelphia evidently kept more closely in mind the experience of London, where brick construction had been mandated by the rebuilding act of 1667. There are dozens of Philadelphia houses_and probably many more - either still standing or known from historic evidence that possessed Flemish checker facades, and some with dates in their gable ends. Due to the greater proximity of Philadelphia houses to one another, however, than those in most of southern New Jersey, they may have been less likely built with decoration in their gables, which requires generous amounts of space to be properly appreciated. It also makes it more likely that such decoration as did make its way into Philadelphia buildings would have been covered up by later buildings that abut them.

The town of Salem was first settled in the late autumn of 1675, two years before Burlington, but it did not grow as quickly as Burlington did, nor did its roster of brick tradesmen. ${ }^{58}$ It was exceptionally well-endowed with brick clay, but the settlement of Salem was less well-sponsored than that of Burlington, and its growth similarly suffered with the founding of Philadelphia just half a dozen years later. Still, bricklayer John Harding signed Fenwick's articles of agreement before leaving England in 1675, and he bought a town lot in Salem in 1685/6, where he lived and

\footnotetext{
${ }^{56}$ This may be the meaning of Joseph Browne's early brickmaking activities in what later became Camden County.

${ }^{57}$ Historic photographs probably provide the best sense of the variety of patterned brickwork in Philadelphia: see Robert F. Looney, Old Philadelphia in Early Photographs, 1839-1914 (New York: Dover Publications, Inc., 1976).

${ }^{58}$ One is often asked whether the construction of individual houses can be attributed to specific building tradesmen. It is occasionally possible to link one or more tradesmen to a given building, but such answers often come, if at all, at the end of a long evidentiary trail. The matter is clouded even more by the fragmentation of the building process.
} 
worked thereafter. Thomas Anderson, of Middlesex, England, may have come with the first arrivals, and he acquired land in Salem County by 1679. Bricklayer William Sirredge was present in Elsinboro Township, just south of Salem, in 1679. He moved his work to Salem in 1684 and remained active there until 1706. Bricklayer Richard Woodnutt II made a career in Salem, from 1688 until his death in 1717. Bricklayer John Clark died in Salem County in 1691, although when he arrived or how long he was active is unclear. A brickmaker, John Mason of Philadelphia, who appears to have been associated with fellow Philadelphia brickmaker Joseph Browne, acquired property in Greenwich (Cumberland County) in 1687, then moved to Elsinboro in 1695. Remarkably, his brick house in Elsinboro still stands (see below). Mason continued in Elsinboro until his death in 1726. Bricklayer Thomas Hasson established himself in Penns Neck Township in the northern part of Salem County by 1697 , and continued there until $1725 .^{59}$

Brick construction began quickly in Burlington, perhaps even more so than in Salem. The first ship of Quaker settlers arrived there late in the year 1677, and aboard were two bricklayers: Samuel Abbett and Francis Collins. They were joined by bricklayers Richard Fenimore and Thomas Kendall in 1681. (It is worth noting in passing that West Jersey was gathering in brick tradesmen at a time when parts of East Jersey were still building chimneys with timber and clay.) Other bricklayers and the dates of their arrival in Burlington (or the dates by which they are known to have been active) include Samuel Houghton (1687), Thomas Douglas (1689), and Thurlas Sullivan (1696). Brickmaker John Petty arrived with his son William in $1678 .{ }^{60}$ Joseph Blowers, Martin Holt, and John Ingram were active by 1683, and Richard Westcott I arrived with his son Richard II in 1684. Brickmaking was such an advanced activity in West New Jersey already by

\footnotetext{
${ }^{59}$ The careers of these and other New Jersey building tradesmen are known mostly from transactional records, but the survival of those records is incomplete, so some of the tradesmen's dates of activity are likely to change as more is learned.

${ }^{60}$ Thompson, Burlington Biographies, 35.
} 
1683 that that year witnessed both its first reported brick-related litigation and its first legislative response. In Browne v. Holt, Philadelphia brickmaker Joseph Browne sued West New Jersey brickmaker Martin Holt over an order of several thousand defective bricks. ${ }^{61}$ The provincial assembly that year enacted a statute setting forth size and quality standards for brick sold in the colony, to take effect in May 1683, just about when bricks being prepared the previous winter and fired that spring would be readied for sale. ${ }^{62}$

As the above suggests, there also was some cross-river movement of bricklayers in the early decades of the colonial period. Richard Woodnutt I worked in Philadelphia before moving to Burlington County by 1684 , and then settled in Salem County four years later. Also, the abovenoted John Mason appears to have taken the transatlantic passage to Philadelphia where he worked for some years before moving to Salem County. Joseph Browne apparently moved from Philadelphia to Gloucester County for a brief interlude about 1688, then returned to Philadelphia. He also evidently returned to Salem County by 1703, and died there in 1711 . Francis Collins, who spent an entire career primarily in Burlington County and in what would much later become Camden County, also did some work in Philadelphia and acquired some property there.

\section{The Spread of Patterned Brickwork in New Jersey}

The first brick houses in Burlington were under construction no later than 1680, according to an anonymous contemporary account published in 1681: "Their Houses are some Built of Brick, some of Timber, Plaister'd and Ciel'd, as in England."63 The first Friends meetinghouse in

\footnotetext{
${ }^{61}$ H. Clay Reed and George J Miller, The Burlington Court Book: A Record of Quaker Jurisprudence, 1680-1709. (Washington, DC: American Historical Association, 1944; reprint Millwood, NY: Kraus Reprint Co., 1975). The court found for the plaintiff. For further discussion, see Chiarappa, "First and Best Sort," 89, and 125, note 40.

${ }^{62}$ For the text of the statute, see Aaron Leaming and Jacob Spicer, Jr., Grants, Concessions, and Original Constitutions..., (Philadelphia: ... 1758; Reprint 2002), 459. See also Harley J. McKee, Introduction to Early American Masonry: Stone, Brick, Mortar and Plaster (Washington, DC: National Trust for Historic Preservation, 1973).

${ }^{63}$ The passage is from the pamphlet, The Present State of the Colony of West-Jersey, in America, September, Anno Dom. 1681, excerpted in Albert Cook Myers, ed., Narratives of Early Pennsylvania, West New Jersey and Delaware 1630-1707 (New York: Charles Scribner's Sons, 1912), 191; quoted in Robert L. Thompson, Burlington
} 
Burlington was a unique, hexagonal building begun in 1685 , that became well-known to Friends as the location that alternated with Philadelphia until 1760 as the site of the sessions of the Philadelphia Yearly Meeting of Friends. This building was demolished between 1786 and 1792, but several hand-drawn sketches exist, and some show that it exhibited a Flemish checker facade. A brick house was built for local entrepreneur and tavern owner George Hutcheson about 1687, also within the first decade of Burlington's history. It was a small house and was a single story tall with a gable roof before being enlarged with a gambrel roof. A house of that size, if it possessed a stone foundation, as was common, would have required about 10,000 bricks, possibly somewhat more, a number that would have been obtainable with little difficulty. Burlington historian Robert Thompson has made a careful examination of the extent of brick construction in early Burlington, including other houses, and chronicled the same in his recent book. ${ }^{64}$

The earliest patterned brickwork in Salem County was built in the southwestern area encompassed today by Salem City and Elsinboro Township. The house believed to be the earliest patterned brickwork building in the county was probably built in the 1690s, but the facts of its construction, including the date, are not supported by the strongest evidence. This was the socalled Bradway house, or Hall-Bradway house, which stood on the north side and near the west end of West Broadway in Salem City, and tradition has long attached the date 1691 to its construction. The house was photographed by Thomas Yorke in 1887, when it still retained most of the elements of its original appearance, but it was devastated by fire in the early $20^{\text {th }}$ century, then was rehabilitated and to a degree remodeled by a local glass company, for its office. The date ' 1691 ' was painted in the upper reaches of the east end wall below the gambrel roof, and many

Biographies: A History of Burlington, New Jersey, Told Through the Lives and Times of Its People (Galloway, NJ: South Jersey Culture \& History Center, Stockton University, 2016), 33.

${ }^{64}$ Thompson, Burlington Biographies. See especially chapter 4, "Houses of Timber and Brick." 
have thought that that paint was applied directly over brick numerals that formed the date. A closeup photo taken in 1964, however, clearly shows that the paint merely covered up plain brickwork. ${ }^{65}$ The house was demolished in 1967, with mysteries of its origin not firmly resolved. Its architectural features, however, clearly placed it in the first generation of patterned brickwork in Salem County, between 1690 and 1720.

Another house that no longer stands was built for Christopher White in $1690-91 .^{66}$ It stood in present-day Lower Alloways Creek Township and featured a bold, brick porch and wraparound pent roofs shielding the first and second stories, and Flemish checker brickwork. This was a unique design, never afterward duplicated in any other Salem County house. Sadly, it was demolished in 1841, before a daguerreotypist in the infancy of photography could take an image of it. A handdrawn sketch was made from memory, after the house was gone. ${ }^{67}$ A second early patterned brickwork house was built in Elsinboro for John Mason, the brickmaker. Almost certainly he and those who worked for him were the bricklayers responsible for the masonry elements of the construction. According to the Salem County historian, Thomas Shourds, Mason's house was built in 1695 and enlarged in $1704 .^{68}$ The second section of the house still stands, on Money Island Road, and embodied within the south wall of that house is the north wall of the former 1695 section, protecting the oldest piece of patterned brickwork in Salem County.

\footnotetext{
${ }^{76}$ See Fenwick's Colony: Salem County Pictorial, 1675-1964 (Salem, NJ: Salem County Tercentenary Committee, 1964), 28. Whether the date was situated somewhere else on the house, or whether it manifested in some other form or was not present at all, remains uncertain.

66 Thomas Shourds, History of Fenwick's Colony (Bridgeton, NJ: G.F. Nixon, 1876), 308-309.

${ }^{67}$ David A. Fogg, Fond Recollections (Princeton, NJ: Backes Graphic Productions, 1997) 164-166.

${ }^{68}$ Shourds, History of Fenwick's Colony, 150.
} 
The Salem Quakers, in their monthly meeting, decided to build a new, brick meeting house in 1699, and decided to hire the local Quaker bricklayer Richard Woodnut to execute the masonry. ${ }^{69}$ This building stood in the lot on West Broadway that contains the Friends' Burial Ground and, until recently, the Salem Oak, and was replaced by the present Friends meeting house on East Broadway in 1772. Although this author has not seen direct evidence of its patterned brickwork, Woodnut is known to have extensively used it in other houses he built, and its spread in Salem County would seem to suggest that this building would have embodied it. Another

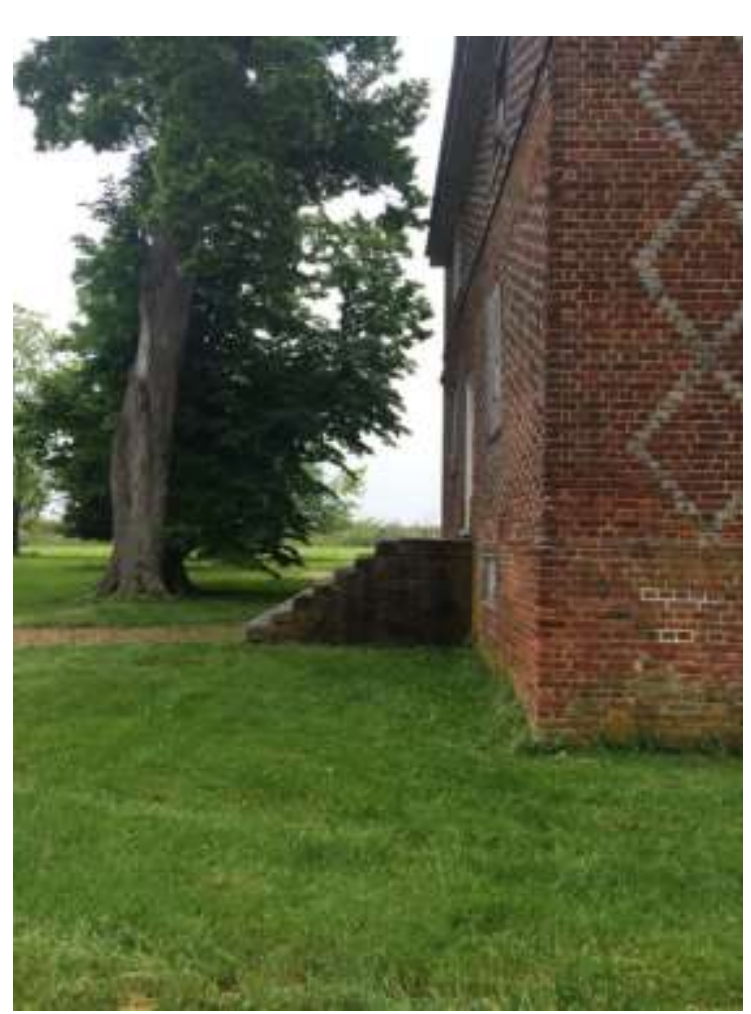

Detail of Abel and Mary Nicholson House, Elsinboro, Salem County, NJ, a National Historic Landmark. Photograph by the author. patterned brickwork house that still stands was built in Elsinboro in 1704 for the Abbott family on the edge of the fast land near the tidal marsh on the north side of Alloways Creek. Other houses joined them in the $1720 \mathrm{~s}$, '30s, and afterward. Together, this neighborhood, including the Hancocks Bridge portion of Lower Alloways Creek Township, deserves consideration as a rural historic district as the most important surviving grouping of early patterned brickwork houses in New Jersey. One of its gems is the Abel and Mary Nicholson house (1722), a National Historic Landmark. Paul Love considered this neighborhood the cultural hearth ${ }^{70}$ of patterned brickwork, certainly in Salem County, but

\footnotetext{
${ }^{69}$ Chiarappa, dissertation, 67.

70 'Hearth' is a cultural geography term, meaning the place where a specific regional cultural practice began, or from whence it spread.
} 
possibly for all of New Jersey. ${ }^{71}$ This latter conjecture, which Love could not prove, seems beyond where the evidence is headed. It seems that Burlington and Philadelphia were independent centers for the spread of this architectural phenomenon, but Salem was at least their equal.

A third mini-hearth, closer to Philadelphia than either Burlington or Salem and one of lesser impact, developed in portions of Gloucester County, including Newton Township and Haddon Township and Gloucester Town (today Gloucester City). ${ }^{72}$ Settlement of this territory began in the 1680s, after that of Burlington or Salem, and appears to have been somewhat more reliant upon Philadelphia directly across the Delaware River. Philadelphia brickmakers Joseph Browne and William Higgins evidently had property in Gloucester County about 1688 and perhaps had brickmaking operations there, but, otherwise, this area does not seem to have developed brickmaking production independent of these men during the period before 1700. Bricklayer Thomas Hester was present there in 1686, but died later the same year. Bricklayer Martin Holt, previously of Burlington County, bought land from Browne in 1688. Bricklayers Thomas Atkinson and Francis Collins, both otherwise from Burlington County, were parties to a Gloucester County land transaction in 1691. Thomas Kendall, also a Burlington brickmaker, moved his residence there in 1700 and remained until his death in 1709.

\section{Spreading Inward from the Port Towns}

Because so many patterned brickwork houses bore dates or initials or both in their end walls (about 40 percent of the total), analyzing these dates can explain the spread of this architectural phenomenon in New Jersey. ${ }^{73}$ Patterned brickwork generally spread from the port

\footnotetext{
${ }^{71}$ Paul V. Love, "Salem Tenth: The Origins and Development of Its Patterned Brickwork." M.A. thesis. Columbia University, 1940.

${ }^{72}$ These areas of Gloucester County were set off to Camden County in the $19^{\text {th }}$ century.

${ }^{73}$ Note: In this document, the construction dates of houses that exhibit their dates in vitrified numerals are indicated in parentheses, eg. (1728); those for which the construction date is known or approximated from other evidence, the information is given without parentheses.
} 
towns on the Delaware River inward. In Salem County, from the Salem-Elsinboro-Hancocks Bridge hearth area, patterned brickwork quickly spread eastward and southeastward throughout Lower Alloways Creek, and to Greenwich on the Cohansey River, and farther to Stow Creek. Both Greenwich Township and Stow Creek Township today are within Cumberland County, but the territory of Cumberland was part of Salem County until 1748, and the western part of Cumberland was settled by Quakers. Patterned brickwork included an early but undated example in the ReeveSheppard house, at the foot of Greate Street in Greenwich, the Nicholas Gibbon house up the street, built in 1730, and the Greenwich Friends Meeting House, built about 1770. Some patterned brickwork houses also are found in other townships farther to the east, including the John and Elizabeth Remington house (1728) in Hopewell Township, and Upper Deerfield townships, including the Isaiah and Mary Sheppard house (1736) in Fairfield Township. The eastern half of Cumberland County was settled chiefly by New Englanders who had a decided preference for timber frame construction. ${ }^{74}$

Patterned brickwork spread through nearly all of Salem County. East of Salem it extended through the townships of Quinton, where the William Tyler house and the William Chandler house (1735) both still stand. In Alloway Township, the William Oakford house (1736), the John Dickinson house (1754), and the Joseph Sneathen house (1765) stand. To the northeastward of Salem, patterned brickwork spread through Mannington Township, where the John Pledger, Jr. house of 1727 still stands. Beyond Mannington lie the townships of Pilesgrove and Pittsgrove, and the Borough of Woodstown, where collectively stand the Zaccheus Dunn house (1743), the Samuel Bassett house (1757), and the Seven Stars Tavern (1762). The Woodstown Friends Meetinghouse (1785) bears its construction date in the gable.

\footnotetext{
74 Joan Berkey, Early Wood Architecture of Cumberland County, New Jersey (Greenwich, NJ: Cumberland County Historical Society, 2015).
} 
Patterned brickwork also spread north of Salem into Lower Penns Neck (today Pennsville) Township. The "Old Guard House" of ca.1735, long since vanished, is still remembered through historic photographs. Very similar to the William Tyler house in Quinton, they exemplified a house form so obscure that architectural historians have never named it. The William Mecum house (1737) was enlarged about 1770 in the Georgian style, extending the Flemish checker facade, and the house still remains among Mecum descendants. Pennsville also includes the Matthias Lambson house (1741). Further north in the $18^{\text {th }}$ century was the Upper Penns Neck (today Oldmans) Township. This township was part of a larger area, extending across Oldmans Creek to Swedesboro, that was chiefly settled by Swedes and Finns who favored log construction and avoided brick construction altogether.

In Gloucester County, which throughout the period of traditional patterned brickwork included the future Camden County, decidedly fewer brick houses were built. Taken together, these two counties produced fewer than half of the patterned brickwork buildings of Salem County alone, and fewer than one-quarter of those of Burlington County. The City of Camden once boasted several patterned brickwork houses, but nearly all have been destroyed, including some within the past decade. The principal exception is Pomona Hall (1726) (1788), headquarters of the Camden County Historical Society. In other towns of Camden County, the Joseph Thackara house (1754) in West Collingswood, the Gabriel Daveis tavern (1756) in Gloucester Township, and Gibb's Tavern (1777) in Haddonfield still stand. In the counties north of Salem, patterned brickwork only appeared in the western half of their territory. The eastern reaches project into New Jersey's Pine Barrens, where clay is not locally available and where transport of brick was inconvenient and expensive. Patterned brickwork came late to the present Gloucester County, with the James and Ann Whitall house (1748) at the Red Bank Battlefield State Park being an early 
example. Only about one dozen examples have been identified within the county, among them the James Whitall, Jr., house (1766) in National Park Borough, and the Thomas Iredell house (1788) in Elk Township.

Burlington County produced the highest number of patterned brickwork buildings in New Jersey, more than 170 have thus far been identified, only modestly fewer than half the total so far identified. Geographically, it was (and is) New Jersey's largest county (slightly larger than now), and possessed the largest population of the southern New Jersey counties during the colonial period..$^{75}$ It was an early adopter of patterned brickwork, but also some of the latest examples were built there. Burlington City had the unusual distinction of being the meeting place for two large groups of Quaker settlers, those from London (the "London Tenth") and those from counties in the English midlands (the "Yorkshire Tenth"). ${ }^{76}$ High Street was the boundary between the tenths. The London group was more familiar with brick construction, and one might expect that most of the patterned brickwork was built within its zone, as it was, but their preponderance over the Yorkshire group was only by a margin of about 3 to 2 , leaving much to look for in the northern townships of the county. Several factors explain this unexpected finding. While the principal early settlers of the Yorkshire Tenth in the 1680s came from counties in England that lay outside the principal geographic region of English brickmaking, and though they were, themselves, more inclined to build in stone than in brick, still they were settling an area of New Jersey below the falls of the Delaware River that was not well endowed with high-quality building stone.

\footnotetext{
${ }^{75}$ See for example, John Brush, The Population of New Jersey (New Brunswick, NJ: Rutgers University Press, 1956): 32-33.

${ }^{76}$ For accounts of Burlington's early years, see John E. Pomfret, The Province of West New Jersey, 1609-1702: A History of the Origins of an American Colony (Princeton, NJ: Princeton University Press, 1956), 102-126; and Robert L. Thompson, Burlington Biographies: A History of Burlington, New Jersey, Told Through the Lives and Times of Its People (Galloway, NJ: Stockton University South Jersey Culture \& History Center, 2016).
} 
In Burlington County, the earliest well-documented house with a date formed by vitrified headers was the John Rogers house (1718). It stood in Burlington Township, a few miles east of downtown Burlington City. From Burlington, patterned brickwork spread out in a 180-degree arc. Moorestown contains the John and Mary Roberts house (1736), Thomas and Hannah Tallman house (1757), and Moorestown Friends Meeting House (1802). In Delran Township the Conrow house (1751) still stands. In Evesham Township, which has been less fortunate in its survivals, the mid- $18^{\text {th }}$ century Daniel Lippincott house is remembered from HABS photographs, and the Jacob Evans house (1769) and Amos Evans house (1785) still stand.

Southeasterly from Burlington, the towns along the Rancocas Creek include Mount Holly, where the mid- $18^{\text {th }}$ century Three Tun Tavern, and the Old Schoolhouse, built in 1759 , still stand. In Hainesport Township the Joseph Moore house (1754), and in Lumberton Township the Amos Wilkins house (1787) and the Eayres house (1789), still stand. The Benjamin Wilkins house (1785) and the William Sharp house (1772) still survive in Medford Township, and Westampton Township includes the Rancocas Friends Meeting (1772) and the site of the recently-lost Aaron and Rachel Wills house (1786). ${ }^{77}$ Above Mount Holly the townships of Southampton and Springfield are rich with patterned brickwork: the Jacob Lamb house (1747), Noah Ridgway house (1753), John Irick house (1761), and several others, including some of the latest houses with dates in their brickwork: the Hollinshead-Peacock house (1786),(1812), and the Woolston house (1821).

Northeast of Burlington in the towns along the Delaware River, Bordentown, like a smaller version of Burlington, contains a cluster of patterned brickwork houses on its principal street, including the Francis Hopkinson house (1730) and the Thomas Buchanan Read house, built about 1765. Fieldsboro contains the White Hill mansion, probably built in the 1760 s. To the east-

\footnotetext{
${ }^{77}$ Destroyed in 2016 by two fires only months apart, and then the ruins bulldozed.
} 
northeast, Chesterfield Township holds the William and Susannah Black house (1740), the Thomas and Charlotte Taylor house (1766), The Locusts (1769), and the Chesterfield Friends Meeting House, built in 1773. Several patterned brickwork houses stand in Mansfield Township, including the Barzillai Newbold house (1740) and the Thomas Taylor house (1765).

A small number of patterned brickwork houses are found in the southern parts of Mercer County and the southwestern fringe of Monmouth County, areas that were a cultural extension of nearby parts of Burlington County. In Upper Freehold, a house on Wygant Road (1766) still stands, but Eglinton, built in 1773, on County Route 524, which had Flemish checker on three sides, has been gone since the 1970 s. $^{78}$ In Mercer County, patterned brickwork is nearly as circumscribed as it is in Monmouth County. Mercer County was formed in 1838, and includes Trenton, the State's capital city. The southern portion of Mercer, including the south half of Trenton, was Nottingham Township in the $18^{\text {th }}$ century and was part of Burlington County. The early building tradesmen there were mostly carpenters, but in 1700 the township was on the eve of the construction of its first stone house. Stone afterward became a popular material, the choice for bridges, a barracks, churches, a courthouse, residences, warehouses, and even the first statehouse. Brick construction might have been skipped altogether were it not for William Trent, Sr., the Philadelphia merchant and Trenton's namesake who was named Chief Justice of New Jersey's colonial Supreme Court. In 1719 he began the construction of a new residence for himself. The house was near enough to completion by the end of 1721 that Trent began to occupy it. It was a departure from prevailing practices in every way. The house was five bays wide, two stories tall, and double-pile, the first house in the future Mercer County to be built to these dimensions. While

\footnotetext{
${ }^{78}$ Eglinton was the home of Robert Montgomery. It was derelict from about 1940 until 1972 when it was destroyed in an arson fire. The remaining walls were torn down in 1975. Its site was finally swallowed up into a housing development in 2016. The house was documented in a collection held by the Hightstown-East Windsor Historical Society, Hightstown, NJ.
} 
it may be argued that it introduced the Georgian style to New Jersey, there is little doubt that it introduced patterned brickwork to the future city of Trenton. ${ }^{79}$

The house was evidently built by Philadelphia carpenters and bricklayers, and likely Philadelphia brick also. Both south and north elevations featured Flemish checker brickwork. Door and window openings on the south side were accented by relieving arches composed of cream-colored stock bricks, probably imported from London. William Montgomerie of Upper Freehold in Monmouth County was evidently impressed by Trent's house and did his best to build a similar one. ${ }^{80}$ He did not have Trent's resources, however, and although he managed to have a two-story, five-bay, double-pile brick house built with a nearly identical floor plan, it lacked many of the refinements of Trent's house.

Patterned brickwork was employed in the William Green house in Ewing Township, probably built in the 1730s, and in the Trenton Friends Meeting House, built in 1739-40. The John Rogers house $(1751)^{81}$ is now a ruin in Mercer County Park. The Brearley house (1761) stands in a Lawrence Township park. The John Taylor house (1769) in Yardville is still a private residence, and the Isaac Pearson house (1773) is owned by Hamilton Township. Brick construction was uncommon in the eastern and northwestern parts of the county. In Princeton, where brick construction was introduced in the 1750 s, the brick houses uniformly display plain brickwork.

\section{The Outliers}

The overwhelming majority of New Jersey's traditional patterned brickwork houses stand in the seven counties enumerated above, but at least a dozen were built in places farther removed.

\footnotetext{
${ }^{79}$ Information about the Trent House is drawn from Susan Maxman Architects, "The William Trent House, Trenton, New Jersey: Historical Documentation and Strategic Planning Study," 1 January 1997. Copy at NJ Historic Preservation Office.

${ }^{80}$ On the north side of Doctor's Creek, on land that William Montgomerie acquired in 1702. This house, also known as the Gruca house for a $20^{\text {th }}$ century owner, long stood derelict until it was demolished about 2000.

${ }^{81}$ John Rogers was from Burlington County; whether he was related to the John Rogers for whom the 1718 house was built is unclear to this author.
} 
The Somers Mansion in Somers Point, Atlantic County, built in the 1720s, stands out among those in other parts of southern New Jersey. More intriguing, perhaps, are a small group of buildings that either stand or once stood in Middlesex and Union counties. The earliest of these houses, popularly known as the Belcher-Ogden mansion in Elizabeth, is understood to have been built about 1680, and it contains some Flemish checker in its facade, but it has undergone so many alterations that it is hard to say when that work was installed. Others include the Jonathan Dunham house in Woodbridge that was built no later than the early 1720s, and would be quite at home if it stood in Salem County. The Parker Castle in Perth Amboy was built up from a stone house of the 1720s that had a patch or two of Flemish checker in its masonry. Recorded by HABS, it was demolished in 1942. And the Proprietary House, built in 1762-64 for the East New Jersey proprietors to the design of imported British architect John Edward Pryor, was the residence of the New Jersey governor from 1774-76. As the seat of the eastern "division" of New Jersey until 1776, the colonial legislature alternated its annual sessions between Perth Amboy and Burlington, which meant that East New Jersey political leaders were aware of the brick houses of Burlington. An isolated and late example stands in Morris County, the John Smith house (1812), the only one of these outliers with its date expressed in brick in the gable.

Even in the communities where the outliers appeared, there tended to be a Quaker presence. The Quakers had a considerable presence in northern Cape May County, for example, one of the original four West New Jersey counties. The Somers Mansion probably built in the 1720s, stands in Somers Point, Atlantic County, across the mouth of the Great Egg Harbor River from Beesley's Point, where a Quaker meetinghouse was built about 1716. The Somers family were Quakers and part of that congregation. ${ }^{82}$ Especially in Middlesex County, however, where

\footnotetext{
82 Jeffrey M. Dorwart, Cape May County, New Jersey: The Making of an American Resort Community (New Brunswick, NJ: Rutgers University Press, 1992), 28-29.
} 
patterned brickwork had a foothold, one can trace multiple paths of Quaker influence. In Perth Amboy, however, and in adjoining Woodbridge, connections with Quakerism were especially strong. Small groups of Quakers resided from the beginning, and in Woodbridge at least by the 1680s, where they built a meetinghouse (of frame) a century later. Also in Woodbridge, Jonathan Dunham's brick house featured a Flemish checker facade and side wall and two hollow diamonds in the west gable. Perth Amboy was established in the early 1680s, when a second generation of Proprietors, led by Scottish Quakers, founded the town. To build it, they brought in building tradesmen, chiefly from London, including a few bricklayers who would have been familiar with patterned brickwork.

\section{Early and Late Adopters}

Paul Love observed that patterned brickwork surged in different counties at different times. He was seeking evidence to support his view that Salem's houses influenced those of Burlington County. He never found a smoking gun of evidence, but he did observe that patterned brickwork found its high tide in Salem long before it did in Burlington County. ${ }^{83}$ The differences are quite significant. Thirty-five Salem County houses have been discovered with dates in their gable ends. These range from 1715 to 1792 , but, importantly, the median date-half the examples earlier and half later-is 1746. In Burlington County, which has had more than 65 examples with similar dates between 1718 and 1802, the median date is 1772. Nearly all of Salem County's examples were built before half of Burlington County's were. ${ }^{84}$

\footnotetext{
${ }^{83}$ Love, dissertation, 61.

${ }^{84}$ The supporting figures are based on New Jersey Historic Preservation Office patterned brickwork data as of August 2017.
} 


\section{The Florescence of Patterned Work in Southern New Jersey: A Spectrum of Colors}

The question of color in the vitrified bricks is an interesting one. Lloyd reported that some of the early British buildings featured bricks vitrified in shades of purple. ${ }^{85}$ Their brick makers produced black headers, of course, but also shades of gray from dark to light. Sometimes light blues were obtained. Reds were possible, and yellow and white bricks could be produced with a clay mixture high in calcium: quite a wide spectrum altogether. Modern brickmakers now know that by manipulating the percentage of carbon in the body of the clay a limited spectrum of colors can be produced, including some shades of green, blue, gray, and black. ${ }^{86}$
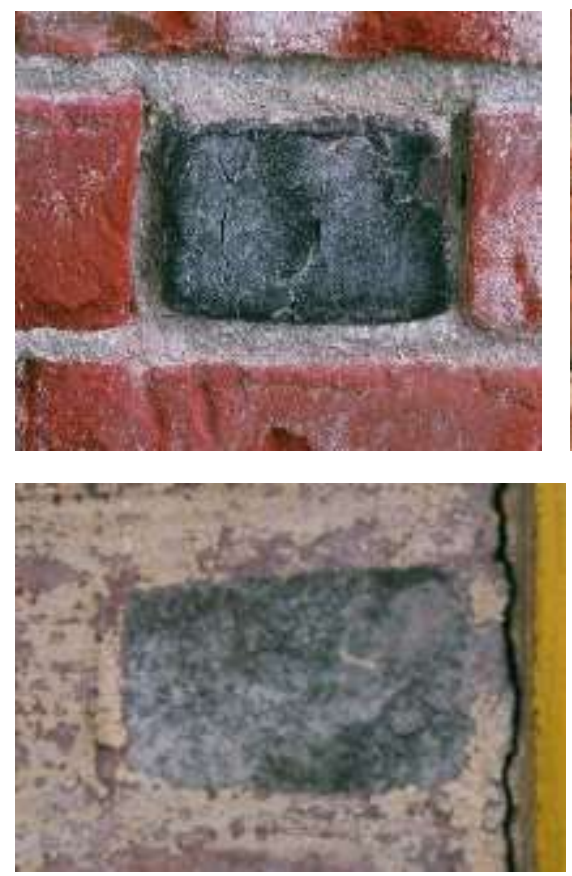
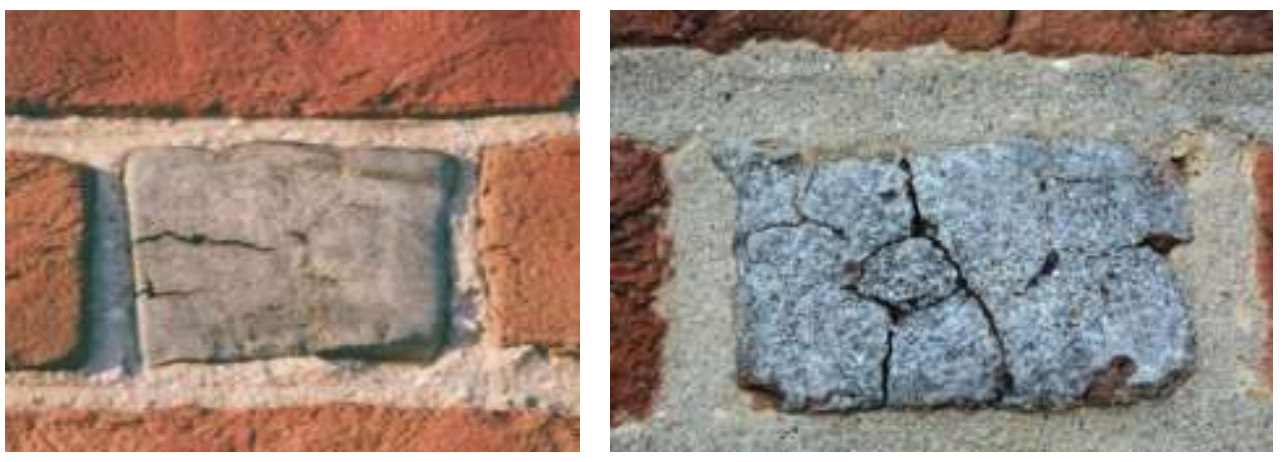

Top, left to right: black, light gray, and bluish gray vitrified headers. Left: green.

Photographs courtesy of Janet Sheridan.

None of the New Jersey patterned brickwork houses displayed purple bricks, and yellow and red vitrified bricks are entirely missing. New Jersey homes usually exhibit their vitrified

brick in shades of black and gray, and these occur across the entire southwestern region of the state. Especially in Salem County, however, several houses were built with brick that was bluish in its vitrification. In at least one house, the Samuel Swing house (1775) in Upper Pittsgrove, a

\footnotetext{
${ }^{85}$ Lloyd, pp.1, 68.

${ }^{86}$ Gerard C.J. Lynch, Brickwork: History, Technology, and Practice, vol.1. (Donhead, UK: House \& Home, 1994), 16, 19-20; and W.B. McKay, McKay's Building Construction (London: Longmans, 1938. Reprint 2003), 12-13.
} 
fancy design in the gable end was carried out entirely in what some sources have identified was a white brick. ${ }^{87}$

White bricks were rarely used in New Jersey. English brickmakers produced a brick in the $18^{\text {th }}$ century that was a near white through the entire body of the brick as well as on the surface. It

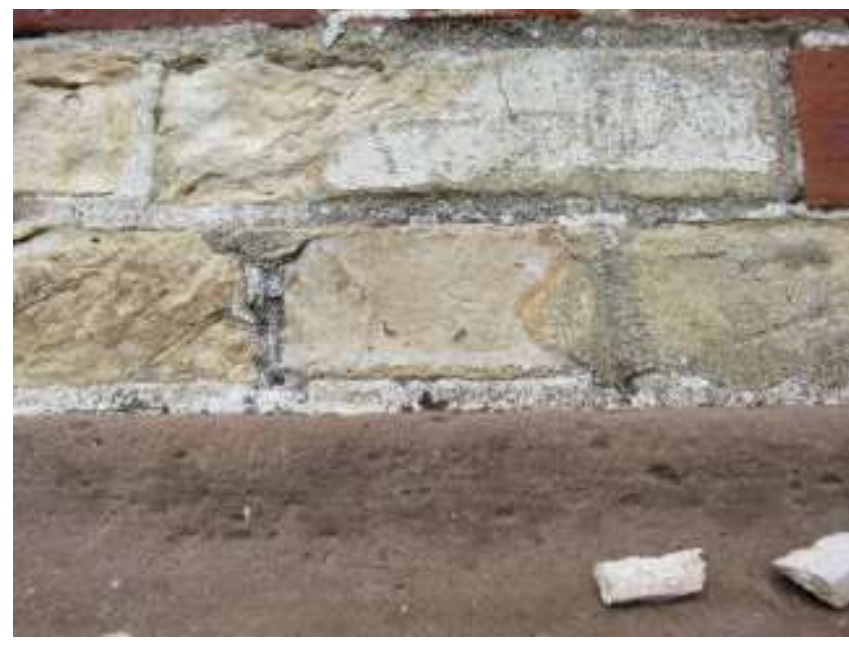

White bricks at Proprietary House in Perth Amboy. Photograph courtesy Jablonski Building Conservation, Inc. is unclear whether Delaware Valley brickmakers had also achieved the production of a white brick. ${ }^{88}$ Several thousand bricks of this kind were used in the façade of the Proprietary House in Perth Amboy, built in 1762-64. Records show that these "white bricks" were purchased from a "Mr. Conoroe." $" 89$

There is no evidence that bricklayers mixed colors to produce their designs. Each instance of patterned brickwork evidently produced a monochrome result. Bricklayers appear to have simply employed the bricks provided to them by the brickmaker or delivered to the client. There is no suggestion in these houses that the brickmakers segregated their vitrified product from unvitrified brick from the same firing, nor that they produced a variety of colors from a single clamp. Such sorting as must necessarily have been

\footnotetext{
${ }^{87}$ It is unclear to this author whether this white finish in the gable end decoration of the Samuel Swing house was vitrified, or applied in some other manner, even as paint. Today this finish is fading and appears less vividly as a flat, whitish, light gray, clearly a much lighter color than the darker gray, vitrified bricks that appear in random locations elsewhere in lower parts of the same wall. In 1976, the color was described as "white" by Johnson, and even before by Love in 1950, who may also have seen it during or before 1941.

${ }^{88}$ English brickmakers also produced a fully gray brick, called a gray stock brick, but it was not vitrified.

${ }^{89}$ John G. Waite Associates, Architects PLLC, "The Proprietary House Historic Structure Report," Prepared for the Proprietary House Association, 1996, p.57, and Appendix B, "Annotated List of Documentary Sources," 4-5. Conoroe is not identified, but other records suggest he may have been related to Isaac Conaroe, a Burlington bricklayer and master builder who was active in the 1730s and '40s. Thompson, Burlington Biographies, 87.
} 
done appears to have been the work of the bricklaying crew. It appears to have been apprentice's or laborer's work.

\section{Flemish Checker}

Only by a deliberate decision of the bricklayer or an instruction by his employer could anything of a decorative character be achieved in brick masonry. Darkened and vitrified bricks often appeared in random places in plain brickwork, especially on rear or secondary elevations, but wherever a coherent pattern is seen, that pattern was deliberately chosen and carried out with the requisite care and concentration.

The simplest effect, and the one most frequently seen, was Flemish checker, which was Flemish bond with the placement of vitrified headers instead of plain ones. Flemish bond had been widely used in brick construction in England since the $16^{\text {th }}$ century when it became the preferred bond for the fronts of buildings. ${ }^{90}$ Brick buildings of the colonial period in New Jersey that did not display patterned brickwork nonetheless ordinarily had a façade of Flemish bond executed in plain brick.

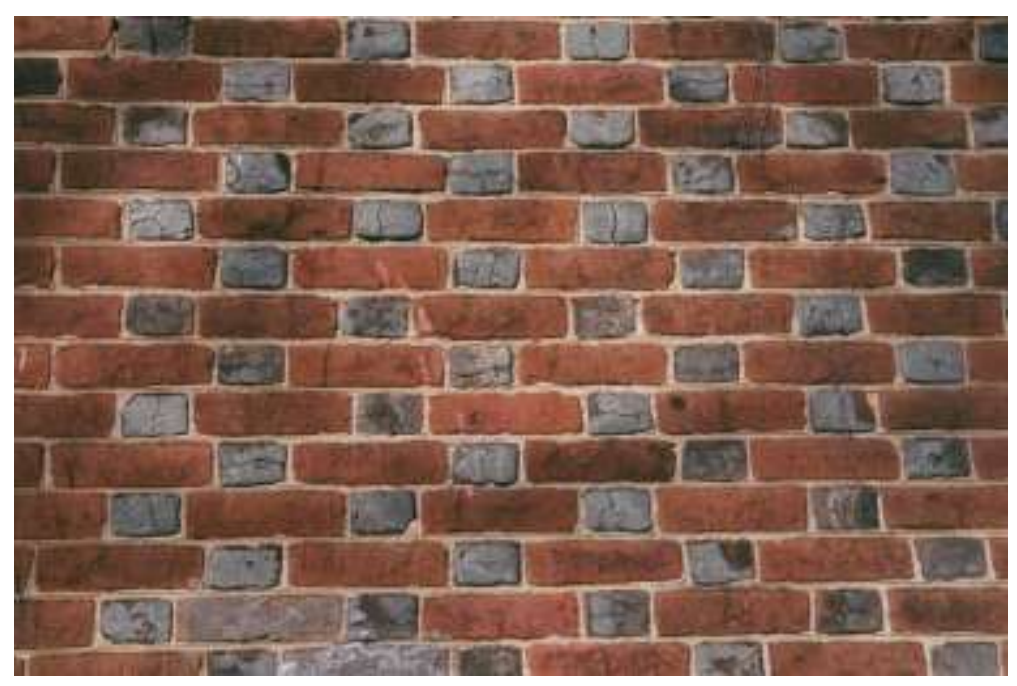

Flemish checker. Photograph by the author.

\footnotetext{
${ }^{90}$ Lloyd, History of English Brickwork, 7.
} 
Flemish checker appeared in perhaps about two-thirds of the patterned brickwork buildings in New Jersey, often together with other patterned work. Its heyday coincided roughly with the $18^{\text {th }}$ century use of relieving arches over entrance and window openings that became a common feature in New Jersey architecture by the 1720s and remained popular in new construction until about $1770 .{ }^{91}$ Often in these arches a vitrified header and a plain stretcher would be alternated, as if voussoirs in a decorative accent that resembled Flemish checker and often accompanied it. These bricks were often gauged or rubbed to ensure that their sides fit as radii to the arch's center (or centers).

Such decorated arches could appear over any opening, but were most common over entrances and first-story windows. They were also frequently constructed over cellar windows and over cellar entrances. They were seldom built over second-story windows, since there were few three-story buildings (outside of cities) and without an additional story above, there was insufficient weight of brick above to require such arches.

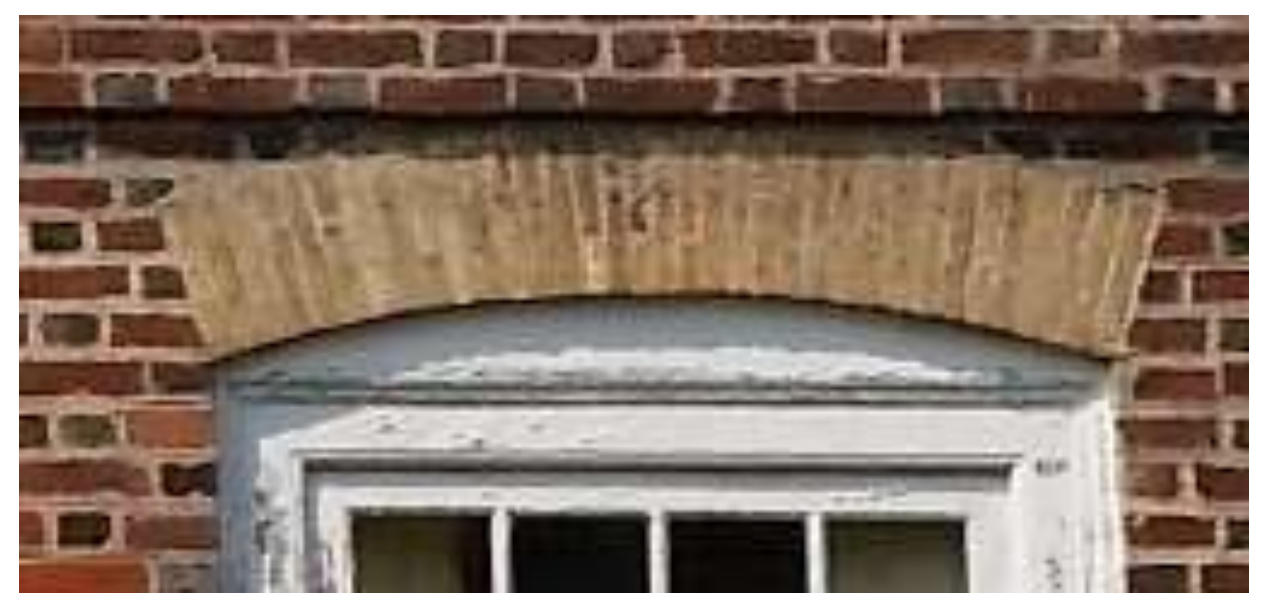

Rubbed and gauged bricks formed into a relieving arch. William Trent house detail. Photograph by the author.

\footnotetext{
91 A 1709 Parliamentary statute required such relieving arches. See, for example, The Builder's Dictionary, vol.2, (1734 edition; reprint 1981), entry for "Windows."
} 


\section{Decorated Stringcourses}

Many Quaker-built houses featured a pent roof (or pentice) above the first story. ${ }^{92}$ This feature was common in frame houses as well, but in brick buildings it required modification to the brickwork. It made necessary a stringcourse, corbeled out from the façade plain, that might be from one to three courses high. The top row of the pent roof's wood shingles would be tucked under the soffit of the stringcourse to keep rainwater from penetrating within. These stringcourses were left undecorated in plain brickwork, but in patterned brickwork houses with a Flemish checker façade, they were sometime incorporated into the decorative scheme.

This could be done in a variety of ways. Even in a facade of Flemish checker, one or more courses of the stringcourse were sometimes left plain. The stringcourse was sometimes laid in Flemish checker consonant with the walls. In other cases, one or more courses of the stringcourse were executed with a vitrified header course. In an unidentified patterned brickwork house in Logan Township, Gloucester County, otherwise covered in stucco, the stringcourse contains a single course of vitrified headers. ${ }^{93}$ Where multiple consecutive courses are laid this way, the effect is known as "header bond." Although in a few Maryland brick houses entire facades are laid in this manner, header bond was never, as far as is known, used in New Jersey in that way, and was not even common in stringcourses.

Stringcourses were sometimes stepped down on their ends, or stepped up, another feature that appeared in New Jersey brick houses in the $17^{\text {th }}$ century and lasted until the middle decades of the $18^{\text {th }}$. Early examples have included the Slate Roof House in Philadelphia, for which dates 1687-1699 have been offered; the Hall-Bradway house of 1691; and the Hinchman-Lippincott house in Haddon Heights, Camden County, believed to have been built in 1699. The value of this

\footnotetext{
92 Fischer, Albion's Seed, 477-479. Fischer traces this element to a popular building practice in the English midlands. ${ }^{93}$ HPO Patterned Brickwork data, record \#172.
} 
feature as a diagnostic device for the age of brick buildings, however, is limited by its continued occasional use over the following several decades.

\section{Zigzags}

Zigzag lines of vitrified headers were an early design motif seen in a very few New Jersey houses, chiefly in Salem County. The two basic varieties are vertical and horizontal zigzags. Examples of both varieties are generally limited to Salem County. The John Worledge house $(1727)^{94}$ in Salem was the principal example in New Jersey of a horizontal zig-zag. Decorations of this type may appear as simply the bottom or top half of a row of diamonds, and may require little change in the underlying bond of the masonry. No examples are known in which a horizontal zig-zag occupied an entire wall. In the Worledge house, the pattern only extends across the width of the house once. It consists of five Vs touching, each ten courses high, as if they were intended to become the bottom segment of a diamond diaper. One unusual example of zig-zags is in the Job Ridgway house (1753) in Burlington County, in which narrow vertical and horizontal zig-zags form a box or rectangle around the date and initials.

The vertical zigzag is a more elaborate pattern, but very unusual. The William Hancock (1734) house in Hancocks Bridge, Salem County is the principal example of the type. In this house, in which the decoration fills the gable wall, ten zig-zags wide, the bond is altered by the use of two plain stretchers in each course between the waving lines of vitrified headers. The stretchers call attention to themselves, however, as part of the overall design, and make the vertical zigzag a bolder decoration than would otherwise be the case. Unlike other diapers, in which the visual effect derives primarily from the figure, itself, the vertical zig-zag derived most of its visual force from how the surrounding bond is changed in response to the shifting lines of headers. The

\footnotetext{
94 This house was recorded by the Historic American Building Survey (HABS) with the identifying number NJ 383. HABS records are available online via the Library of Congress website.
} 
headers are normally flanked by stretchers, and their presence highlights the effect. In this respect, the vertical zig-zag was the only one of the diapers that required a conspicuous change in the surrounding brickwork to ensure its effectiveness. The Nathaniel Chambless house not far away is another example of the vertical zig-zag diaper, quite similar to Hancock, but a lowering of the roof in the $19^{\text {th }}$ century renders this decoration incomplete. It seems likely that the same unidentified bricklayers undertook the masonry of both houses. Local historians believe the Chambless house was built first, and Love speculated that the Hancock house was copied from it, but convincing evidence is still needed, and the priority may, in fact, have been the other way. ${ }^{95}$

\section{Banding}

At least one dozen patterned brickwork buildings were built with a pattern that Love and subsequent writers have called "horizontal banding." Love defined it as the laying of one or more courses of vitrified headers across the length or width of an entire wall. Since there were no instances of vertical banding in New Jersey, it might be better to simply call it "banding." Nearly all buildings that exhibited banding were built in Burlington or Camden counties. Love attributed this outcome to a fundamental difference between Burlington and Salem County houses. Cultural geographer Peter Wacker also observed this difference. Salem County houses tended to be wider than deep and were more often single-pile. Burlington County houses, perhaps following a London influence, were narrower in front than in depth, and double-pile. ${ }^{96}$ Both county's houses tended to exhibit pent roofs, but those of Salem County were most often limited to the front and rear, while those of Burlington County often wrapped around the sides of the house. In many cases these pent roofs were built between the first and second stories and a smaller pent roof at the eaves

\footnotetext{
${ }^{95}$ Love, dissertation, 39.

${ }^{96}$ Love, dissertation, 63; Peter O. Wacker, "New Jersey's Cultural Landscape Before 1800," Proceedings of the Second Annual Symposium of the New Jersey Historical Commission ... December 5, 1970 (Newark, NJ: New Jersey Historical Society, 1971): 35-62.
} 
level. Where this practice was employed, Burlington County houses were without the opportunity to include designs that mirrored the diapers of Salem County. Apart from Flemish checker, banding was the one design available to bricklayers to decorate the end walls in the first and second stories, even though it was not often used. Banding was also used in a few houses below the water table. The Jabez and Elizabeth Woolston house in Mount Holly offers a minor example of horizontal banding just above the foundation, as if the masons had suddenly been ordered to stop what they had begun. The Wright house in Smithville, Burlington County also confined horizontal banding to the foundation area, but in this case it was evidently a deliberate decision fully carried out.

Banding emerged late. Few examples possess dates in vitrified brick, but the earliest one yet found is the Richard Eayres house in Eayrestown (1769). Banding may have been encouraged by the emergence of a similar practice, underlining. In the Quaker meetinghouses of Rancocas (1772) and Salem (1772) the date in the gable was underlined by one course of vitrified headers that extended the length of the date. The date of the Eayres house seems something of an anomaly, however, as examples of banding otherwise cluster in the 1780s, and early 1790s. The Woolston house was built in 1783, according to an inscribed brick in the facade. The Charles French house in Cherry Hill (1785) and the Gaskill house (1792) in Springfield Township have their dates in vitrified brick. The Field-Stevens house in Fieldsboro exhibited an early Federal style design, which likely places its construction in the 1780s, and the Wright house, which has begun to lose its stucco and will one day reveal a date behind it, appears likely to have been built in the 1780s 
also. ${ }^{97}$ Even the Cornelius Copner house, one of only two examples of banding in Salem County, appears highly likely to have been built in the 1780 s. $^{98}$

Two other related forms of decoration should also be considered as banding. These include what Love called "pediment-outlines," which was a line of vitrified headers that paralleled the fascia boards that traced the line of the roof slope. There were versions for both the gable and the gambrel $^{99}$ roof, although the former predominated, being easier to execute. Love discussed these decorations along with the diaper treatments, for they sometimes occurred in the same buildings, but he also conceded that they were not diaper treatments themselves, and should be classified as banding. ${ }^{100}$ The pediment outline as a separate decoration began to appear in the 1740 s. It was used in the Matthias Lambson house (1741) in Pennsville Township and the Ware-Shourds house (1758) in Lower Alloways Creek Township. In the 1760s, however, it further came into its own when it was combined with a small diamond in the apex of the gable. This appeared in at least three houses during that decade, including the Thomas Taylor house (1765) built in Georgetown, Burlington County; and the John Taylor house (1769) in Yardville, Mercer County. ${ }^{101}$

\section{Diamonds and Diapers}

Apart from Flemish checker, the earliest designs in vitrified brick included hollow diamonds, composed of an outline of vitrified headers and a center of plain brickwork. Diamonds could appear in individual isolation, as in the diamonds that flank the entrance, one on either side,

\footnotetext{
${ }^{97}$ Love, dissertation, 152, noted that a datestone on the building inscribed with the date 1725 was installed by the owner in 1936, an act of prochronistic deception.

${ }^{98}$ Johnson, 27 in '76, 40-43. Sickler gave a date of ca.1740 for the Copner house, but the physical evidence of the building does not support such an early date. Love agreed that the house was probably later than ca.1740. Love, dissertation, 157.

${ }^{99}$ For example, in the Richard Smith house (1729) in Elsinboro Township.

${ }^{100}$ By definition, a diaper is the repetition of a small design spread two-dimensionally over an entire wall, whereas the pediment outline was simply a single design across the width of a gable.

${ }^{101}$ Whether there was a family relationship between the two Taylors has not been examined.
} 
to the Gloria Dei Church, built in $1698-1700$ in Philadelphia. ${ }^{102}$ These diamonds were of an unusual size and configuration. They were of thirteen courses high, and had a single vitrified header at their centers. This precise formula, almost never seen in southern New Jersey, does, however, match the diamonds in what was the north wall of the John and Sarah Mason house of 1695, which gives added credence to the accepted date for that early building. ${ }^{103}$ In the Mason house, however, the design in the end wall is a grouping of hollow diamonds that touch at their apices (points) in a group probably two diamonds high by three wide. ${ }^{104}$

The Hall-Bradway house in Salem, believed to have been built in 1691, also featured diamond designs in both gable ends. ${ }^{105}$ The house featured a matrix of three diamonds wide by two diamonds high, joined at their points. The design was laid in the first story of the west gable end and repeated in the east side. The design was most easily seen in the Thomas Yorke photograph of $1887 ;^{106}$ it consisted of another diamond matrix three diamonds wide by two high. The construction date of the Hall-Bradway house has been in some question, however, because the numerals were painted on (see below), but the similarity of the diamond matrix to that of the Mason house lends the construction date some circumstantial support.

The Rogers house (1718) in Burlington Township, was the only Burlington County house that possessed the same type of diamond matrix. HABS drawings show that it possessed one matrix in the gable end of three diamonds wide by two high, below the initials and date, and two

\footnotetext{
102 This Swedish Lutheran church was built by English carpenters and masons. See Roger Moss, "The Master Builders," 44-45; Chiarappa, dissertation, 69.

${ }^{103}$ The earliest portion of the John and Sarah Mason house, is understood from Shourds to have been built in 1695. It also had Flemish checker in its lower portion below the diamond matrix.

${ }^{104}$ Discussion of the John and Sarah Mason house diamond decoration is somewhat tentative, because the design is not fully revealed from the plaster that covered it.

105 The patterned work in the Hall-Bradway house can best be seen in a postcard of the house in the collections of the Salem County Historical Society. See also Love, dissertation, 25-26, where he notes that the diamond designs were arranged on either side of a central window. That central window is hard to discern from the postcard, but the postcard clearly shows evidence of a bricked-up central window in the comparable location in the first story.

${ }^{106}$ In the Yorke collection, at the Salem County Historical Society, Salem, NJ.
} 
matrices on the rear elevation, each three diamonds high by three wide, the only house in southern New Jersey with this formula. This house is remembered from measured drawings produced in 1936 and photographs taken for the Historic American Buildings Survey in 1936 and 1937, but, sadly, the house--already derelict when it was recorded--was demolished in 1941. ${ }^{107}$ It may have been the last house built with this form of diamond matrix. The diamond diaper design shortly followed.

Richard Smith house (1729) contains a single horizontal row of diamonds, as if a horizontal zig-zag were doubled and flipped, positioned at the base of the end wall. The “General Clinton's headquarters" house in Mount Laurel Township (1740?), had a double diamond matrix just under the eaves level and just below where the date is positioned. ${ }^{108}$ Diamonds also sometimes appeared in small groups. The Jonathan Dunham house in Woodbridge, Middlesex County, also contains a pair of small, hollow diamonds, touching at their side corners, in the west end wall of the house. Individual diamonds are sometimes associated with pediment outlines (see "Banding" above). Diamonds in small groups were sometimes placed in gable ends along with dates (see below). Diamond "diapers," which featured diamond motif repeated across the entire height and width of a wall, were executed almost exclusively in Salem County. At least one was built in Cumberland County at a time when it was part of Salem County. Such diapers did not appear in Burlington County, and it took more than a generation for the full diamond diaper to appear in Salem County. At least among surviving buildings, it was first achieved in the Joseph Darkin house (1720) in Elsinboro, coincidentally the earliest known Salem County house to feature a date in the gable in

\footnotetext{
107 William B. Bassett, Historic American Buildings Survey of New Jersey: Catalog of the Measured Drawings, Photographs, and Written Documents in the Survey (Newark, NJ: NJ Historical Society, 1977), 167.

${ }^{108}$ HABS NJ 504. The HABS drawing that shows this elevation gives the date 1740, instead of the date 1764 that Love accepted (Appendix A). If the latter date is correct, then the house would have been architecturally retardataire when built. Its features place it comparable to other buildings of the 1740s.
} 
vitrified brick. The Darkin house was closely followed by its near twin, the Abel and Mary Nicholson house (1722), also in Elsinboro. For about the next 25 years, about one dozen examples altogether are known or expected. These include the John Maddox Denn house (1725) and the Joseph and Christiana Champneys house (1746). The David Davis house, built about 1730, has a diamond diaper in its gable end, but no date in the brickwork. Still, based on design features, it seems likely to have been built within the scatter of dates of the others. The Ephraim Padgett ${ }^{109}$ house, also undated in brick, is thought to have been built about 1735. The Wright house on East Broadway in Salem is entirely covered in stucco, but a historical record places its construction in 1726, and the nature of its construction makes it another suspect for a diamond diaper. In Cumberland County, the John and Elizabeth Remington house (1728) and the Isaiah and Mary Sheppard house (1736) also feature diamond diapers.

To execute such a diaper required more skill of the bricklayer than meets the eye. Careful planning was needed to center the effect from front to back. The easiest method would have been to find the midpoint of the side once the water table course had been laid, and begin to lay the base course for the diamonds outward from that point. No statement of how bricklayers actually achieved this feat appears to have been reported. Bricklayers laid diamonds as small as nine courses high (Padgett house) and as high as 23 courses (John Maddox Denn house). One curiosity of these designs was, however, that since the diamonds were always symmetrical, when their top and bottom points were both counted, their courses always resulted in an odd number. The design, however, was ordinarily laid in a field of English bond, which is an even number of courses. This meant that while outside the figure of the design it was simple work to preserve a consistent English bond, inside the figure presented a situation fraught with a fundamental difficulty. If the

\footnotetext{
${ }^{109}$ This house was built about 1735, probably for James Evans, and was purchased by Padgett in 1860 (Janet Sheridan, personal communication).
} 
English bond was in a stretcher course at the bottom of a diamond, it would be so at the middle and at the top, but the spacing within the diamond would call for the opposite treatment: a header in the third course (second course above the point), whereas outside the figure a stretcher would be laid in that course. In the next course, the spacing within the diamond would call for a stretcher, whereas outside the design the bond would call for a header, and so on. Furthermore, while the same approach could be taken with all diamonds that were on the same level, and all diamonds that were tangent at their points, adjoining diamonds that abutted one another on their sides required the opposite treatment. To do so consistently would heighten the visual effect of the design — creating a different sort of checker — in much the same way that the vertical zig-zags were heightened by the laying of stretchers on either side. To fail would make the brickwork within each diamond look sloppy. But it required the bricklayer to make a decision at the beginning, and stick to it: favor the English bond of the overall wall, or favor the spacing needs within each diamond. This back-and-forth called for the utmost concentration.

A bricklayer inexperienced in laying this design would have been surprised that so much was involved in something so apparently simple. Even the bricklayer of the Abel Nicholson house couldn't get it completely right, leaving behind hundreds of inconsistencies, as evidence that he couldn't make up his mind. Love, who analyzed the skillfulness of each of the diapers he found, held that none were completely satisfactory and that all merited some criticism. The designs ranged from three diamonds (Denn) wide to eleven (Padgett). One diaper would not close properly due to faulty centering, and there were errors at the top sometimes caused by awkward efforts to link the diaper to a pediment outline. Love found that with the 11-diamond-wide pattern of the 
Padgett house, the "design was created in the process of building and was not carefully planned beforehand."

\section{Coronets and Other Unique Designs}

The diamond matrices and the diamond diapers were associated with the early generations of Quakers in the Delaware Valley, the generation that pioneered there in the 1670 s and ' 80 s, and their children's generation, the last one appearing in the $1740 \mathrm{~s}$. There was one final design, however, that, even though it wasn't a diaper by definition, it still occupied the entire end wall of a house. John Dickinson of Alloway Township, Salem County, had his house built in 1754, and from the attention it has received in recent decades it has become the single most popular example of New Jersey patterned brickwork. It does have its virtues. It contains the greatest volume of vitrified brick of any end-wall design, and it introduced the solid diamond-30 of them, large and small — for the first time to the patterned brickwork repertoire. It is both well-centered from front to back and well-balanced from bottom to top. It displays a complex and perfectly symmetrical structure of diamonds, solid and hollow, connected with branching diagonals. The pattern is evocative. It remains in some ways the high-water mark for patterned brickwork in the Georgian period, and it is an original design, uncopied either in England or America.

Yet from the bricklayer's point-of-view, it was not the most difficult design to execute nor does it reflect the highest skill nor the greatest level of effort. The entire design of diamonds and diagonals was executed in vitrified headers laid in their normal orientation and positioned stepwise within a field of plain Flemish bond. In effect, the bricklayer was able to achieve such an elaborate composition only by simplifying its individual components. Only in the initials of the owners and the numerals of the date did he deviate from this practice. There, in the vertical strokes

\footnotetext{
${ }^{110}$ Love, dissertation, 37.
} 
of the numerals, he turned the headers to effect a slant in the ' 1 ' and the ' 7 ,' and similarly in the ' 5 ' and the '4.' This gave the numbers an attenuated look that nicely sets them apart from the structure of the diamonds. The numerals, however, look better in the HABS drawing than they do in photographs, for in fact the ' 1 ' and the ' 7 ' start two courses below the ' 5 ' and the ' 4 ,' although they all finish in the same line. Of the initials, the surname initial ' $\mathrm{D}$ ' is slightly off-center and rests too low on the diamonds beneath it, while the 'I' and the ' $M$ ' are of slightly different heights.

The Dickinson house evidently influenced the builders of the Samuel and Anne Bassett house (1757) in nearby Pilesgrove Township, which despite its much smaller gable end design, exhibits numerals very reminiscent of the Dickinson house. The Bassett house evidently introduced a band of underlining below the date for the first time. The manner in which it was turned up into a diagonal at either end suggests that it was the precedent for the same feature in the Salem Friends Meeting House (1772). The date is split in half by a column of three diamonds between the ' 17 ' and the ' 57 .' This is the first of two ${ }^{111}$ houses that feature a coronet (small crown) in the gable. It, too, is fashioned step-wise with each of the headers in its normal orientation. The overall design, including letters and numerals, is only half the size of the Dickinson house design.

Eighteen years later, the Samuel Swing house (1775) was built in Upper Pittsgrove Township with a coronet evidently copied from the Bassett house. There the design was carried out with a much better balance in the letters and numbers. This house features the design in the east gable, similar to the Bassett house, and its design in white brick (as noted above) would have been seen at its finest in the morning. The evidence for another coronet appears in the attic of the Mayhew-Isaac Johnson house (1762), in Upper Pittsgrove Township.

\footnotetext{
${ }^{111}$ A third house, on the highway from Salem to Quinton, which copies the coronet, is a mid-20 ${ }^{\text {th }}$-century imitation, a piece of flattery good enough to fool the unwary.
} 


\section{Initials and Dates}

The practice of working dates in patterned brickwork into the gables of houses can be seen as part of a larger phenomenon observable at least since the Reformation, to inscribe buildings with their dates of construction. Such actions were not limited to the American colonies but were certainly widely practiced there. Dates were inscribed in numerous ways and in several different materials, including wood, stone, and metals. Even in brick, inscribing dates in houses was done in several different ways, of which patterned brickwork was the most conspicuous and probably the most frequently practiced. ${ }^{112}$ In Quaker West Jersey, the initials stood for the original owners of the house - husband and wife - the clients for whom it was being constructed. Ordinarily, the surname initial is placed above the given name initials, the husband's appearing below and to the left, the wife's below and to the right.

The practice of placing the year of construction of a house in vitrified brick in the end wall of a house began as early as 1715 , according to a painting in the collections of the Salem County Historical Society. ${ }^{113}$ In 1718, an elaborate, although small, patterned brickwork house with diamond matrices was built for a John Rogers in Burlington Township, Burlington County. It not only featured the date in large awkward numerals, it also displayed the owners' initials "I R R." This was the earliest known instance in which either the date or the owners' initials were represented in vitrified brick. The oldest surviving patterned brickwork house that bears its construction date in vitrified brick is the Joseph Darkin house (1720) in Elsinboro Township, Salem County. That date is captured in small numerals, laid by a tradesman apparently already

\footnotetext{
112 Dates were also inscribed in datestones set into brick walls, and in wet plaster mounted as plaques framed with molded brick and set into walls. Individual bricks were also inscribed in their bedding planes by brickmakers before firing, or inscribed on their faces by family members or others, who also included their initials. These bricks were often laid into spaces about chest-height on either side of the front entrance, and sometimes disposed with perfect symmetry, indicating that their installation was done with a symbolic importance or in a ceremonial event.

113 The painting, in May 1886 by Salem artist James H. Simkins, depicts a 1+1/2-story gambrel-roofed brick house with the date in the end wall, but the artist did not identify the house.
} 
comfortable in doing so, meaning that it was likely not his first time. The near-identical twin of this house, the Abel and Mary Nicholson house, was built in the same neighborhood in 1722, and the numerals are laid in the same manner, apparently by the same unidentified bricklayer.

The Rogers house (1718), with its bold diamond matrices, was possibly influenced by a still older Salem County house, the Hall-Bradway house believed to have been constructed in 1691. That date was rendered in paint in the east gable of the house, up near the peak. That the date was painted has led some to suspect that the date may not truly have been present in the brick there - a prochronistic piece of wishful thinking — or that it might have been expressed in some other fashion. ${ }^{114}$

In this case, however, it is possible to doubt the accuracy of the paint work. Although several photos of the house are known showing these numerals, the most revealing one appeared in 1964 in the book Fenwick's Colony, published by Salem County to commemorate the New Jersey tercentenary. ${ }^{115}$ The text that describes this photo admits that the numerals in the gable are painted, but asserts that the paint overlies the numerals executed in vitrified brick. A careful study of the photo, however, disproves this. The general shape of the numerals is such that no bricklayer could have produced the slender lines and curves. Even more to the point, the bricks and mortar joints adjacent to the painted numerals show in numerous places that there were no brick numerals underneath. Such inconsistencies occur in at least six places with respect to the painted "1," eleven or more places with the " 6 ," about as many places with the " 9 ," and perhaps nine places with the

\footnotetext{
${ }^{114}$ It has not been uncommon for the dates to have been painted over in a darker color, often black. In other cases inspected by this author in which the date has been painted in that manner, the paint has been found to be covering numerals laid brick. That was not the case, however, with the Hall-Bradway house.

115 Salem County Tercentenary Committee, Fenwick's Colony: Salem County Pictorial, 1675-1964 (Salem, NJ: Sunbeam Publishing Co., 1964) 26.
} 
trailing "1." If there was a date in vitrified brick in this house at that time, it did not exist in that location. Love also carefully inspected this date and came to the same conclusion. ${ }^{116}$

The styles of laying the letters and numerals varied considerably. The simplest and most frequently encountered, merely involved laying vitrified headers in the ordinary horizontal manner, in the places where they were needed to complete each figure. Slants, as with a ' 1 ' or a ' 7 ' became verticals, and diagonals in the numerals ' 2 ' and ' 4 ' were executed in stepwise fashion. For the bricklayer, the more artful the numerals the more time-consuming the execution. To produce work that resembled a script handwriting, it wasn't enough to merely craft the figure, itself; the bricklayer also had to craft the void into which the figure would be laid-both the inside curve and the outside curve. Thus the more sculpted the numeral, the more nuanced the void. Many of the houses that exhibit dates display numerals that were executed in the simplest fashion. A ' 1 ' for example was a vertical column of headers that only minimally impacted the bonding of the bricks on either side. A ' 7 ' was merely a ' 1 ' with an added horizontal row of headers at the top. A date such as ' 1771 ' could thus be easily accomplished. In some cases, slants were given to the vertical strokes of these numerals.

Enclosed numerals did not necessarily pose much trouble either, when executed simply. Curves could be avoided by laying bricks in vertical or horizontal orientation only. The ' 0 ' and the ' 8 ' were often handled straightforwardly in a boxy fashion, while the ' 3 ' could simply be handled as an ' 8 ' without the left-side verticals. enclosed portions of the ' 6 ' and the '9' were mirrors of one another. The '4' could cause more headaches for the bricklayer. One man-perhaps dyslexic_-laid the '4' backwards when installing the date '1741' in the Fogg family farmhouse in

\footnotetext{
${ }^{116}$ Love, dissertation, 25.
} 
Stow Creek Township. Two years later, another bricklayer, a few miles away, produced an even more awkwardly laid ' 4 ' in the ' 1743 ' of the Zaccheus Dunn house in Pilesgrove Township.

For numerals with clear diagonal strokes, such as the '2', some bricklayers constructed them merely by laying headers horizontally in stepwise fashion. The '5', however, even when constructed simply, required more patience and concentration to ensure that the vitrified headers were laid in the right places. A bricklayer not practiced in this work could easily lay an awkward '5', as in the Rogers house in West Windsor Township, Mercer County (often mistaken for a '6'). But there were at least a few bricklaying teams who aimed to give their numerals a script-like appearance, complete with slants, serifs, and smooth curves. The dates of several houses were laid in this manner. In these houses, the bricklayers added to the slants of the ' 1 ' and the ' 7 ' a single header at the end of each stroke as the brick equivalent of a serif. The serif could be made in either pointed or unpointed versions. Numerals that when written end in a curve, such as '6' and '9', were laid so that the bricks actually formed smooth curves, sometimes even tapering the width of the bricks to terminate these strokes in a sharp point. Sometimes the '9', for example, terminated in a curve below the baseline of the other numerals. This might be a short taper in less painstaking work, or a much longer taper in the best work. In addition, the strokes of some numerals have an upward flourish. Where the ' 5 ' appears in these houses, it has been given a curved upward finishing stroke. In the finer work, bricklayers also manipulated the orientation of the bricks within the curve of each figure. This often meant turning the header perpendicular to the radius of the curve, and adjusting the edges with a brick chisel or by rubbing to make a smooth joint with the next header. Sometimes bricklayers used some of the small number of vitrified stretchers that brickmakers would incidentally produce in their firings. There is no clear evidence that bricklayers ordered, or brickmakers produced, deliberately molded or specially fired brick intended in advance 
to be used in the composition of initials or dates. One might speculate that a bricklayer, faced with a complicated design to execute, could have laid out the design beforehand on a board, thereby perfecting it, but no contemporary document explaining how a representative bricklayer performed these tasks has been found. And there was a counter-intuitive element to the fashioning of dates and initials. When one prints Arabic numerals or writes capital letters on paper, one generally begins at the top of the figure and works downward, and even though some letters require more than a single stroke of the pen, within each stroke the movement is continuous. To fashion letters or numerals for a brick house, however, one had to work more or less in the reverse order. From the bottom to the top. Which posed few challenges when the strokes could be achieved with straight rows or columns of vitrified headers. But with some numerals executed in a script fashion, curved lines were paramount. The "1", “4”, or "7" could be simply carried out with straight lines, except in a few cases, but the other numerals all posed issues with curves that would break the horizontal lines of brick bonding that were otherwise not deviated from. And with a " 5 ", for example, the lowest part of the bottom of the curve would occur in the middle of the figure that was neither the start nor end of the line.

\section{Impact of Patterned Brickwork on Construction Cost}

Any additional work that slowed the pace of a bricklayer's progress would have added to the cost of a building. It was generally understood, based on English experience in the rebuilding of London, that a bricklayer, working with an assistant to supply him with bricks and prepare mortar, could be expected to lay about 1,000 bricks per day in ordinary, plain brickwork. Builders' manuals analyzed this type of cost experience. ${ }^{117}$ In 1707 , when the Chesterfield Friends built a

\footnotetext{
${ }^{117}$ Lloyd, 23-24; and the authors of the various builders' manuals were in general agreement.
} 
brick meetinghouse that probably contained 35 thousand bricks, the bricklayers were paid over $£ 33$ for their labor. ${ }^{118}$

Even Flemish checker, the one type of diaper work that probably least affected the rate at which a bricklayer could perform, was dispensed with in any location where it would not be seen. In New Jersey houses that displayed pent roofs, for example, Flemish checker was never wasted on those areas that would be covered by such a roof. Plain brickwork, usually in English bond, was employed instead. This would not have been done merely to conserve the supply of vitrified headers, though it would have that benefit.

The time-consuming tasks involved in laying the numerals must have added hours to the bricklayer's work and cost to the building's construction. Efforts to determine how much this must have added to the bricklaying cost have not been made, nor a contemporary document found that explains such extra charges, but as a conservative guess, it seems likely to have added at least a shilling per character to the cost, at a time when bricklayers earned only a few shillings per day. Even a single letter or numeral would require the bricklayer to correctly make dozens of departures from ordinary bricklaying. For these reasons, the authors of the builders' manuals recommended that bricklayers needed to be compensated an additional, negotiated amount for diaper work or special designs, at least those that could not be accomplished in a step-wise fashion. The standard bricklaying rates did not apply for these or other types of extraordinary decoration. And the use of white brick also added to the cost. ${ }^{119}$

\footnotetext{
${ }^{118}$ RG2, Ph/C47/6.4, Friends Historical Library, Swarthmore College, Swarthmore, PA. 33,000 brick were provided for the work as it went forward, and another 3,000 were needed to finish it.

${ }^{119}$ Proprietary House HSR, Appendix A, 4-5.
} 


\section{The Analogy to Linen Cloth}

Bricklaying lent itself easily to cloth-making analogies, certainly in hindsight. ${ }^{120}$ The connection is inherent in the use of the word diaper, which OED has found that

since the $15^{\text {th }}$ [century] applied to a linen fabric... woven with a small and simple pattern, formed by the different directions of the thread, with the different reflections of light from its surface, and consisting of lines crossing diamond-wise, with the spaces variously filled up by parallel lines, a central leaf or dot, etc. In earlier times, esp. in Old French or medieval Latin, the name was applied to a richer... fabric... woven or flowered over the surface with gold thread. ${ }^{121}$

Flemish bond was like a simple, plain weave in which the warp was of a wider diameter than the weft. Flemish checker was like that same plain weave, but in which the warp was of a darker color and more reflective texture. It was not uncommon for images of homes to be stitched into girls' samplers, by which they demonstrated their skill in embroidery. Nearly every design that was executed in patterned brickwork had its counterpart in $18^{\text {th }}$-century samplers: Flemish checker, zig-zags, diamonds in rows and matrices. Betty Ring, in her history of this type of embroidery, featured some startling examples from the 1720 s and ' 30 s, suggesting that the girls who stitched them were very familiar with houses that embodied the same patterns. ${ }^{122}$

Damon Tvaryanas also raised the issue of how dates were handled in buildings, and saw an evident linkage to cloth there as well. While he found no compelling evidence to ascribe cause and effect, he wrote that "the most likely sources for [the bricklayers'] patterns were the domestic textiles that they probably encountered on a daily basis." 123 "Overall," he added, "the similarities between patterned brickwork and needlework were greater than the differences, and thus it is only

\footnotetext{
${ }^{120}$ Love observed the similarity of patterned brickwork to the designs in samplers, but did not elaborate upon this insight; see dissertation, 58.

${ }^{121}$ OED online, "diaper."

${ }^{122}$ Betty Ring, Girlhood Embroidery: ... 1650-1850 (New York: Alfred A. Knopf, 1993), especially 328-336.

${ }^{123}$ Tvaryanas, "Parallel or Precedent," 45.
} 
logical to suggest that there would have been some cross-fertilization."124 Tvaryanas also analyzed how the manner in which the brickwork of owners" initials resembles "the rule to mark napkins" that was adopted somewhat later by samplers produced by the students of certain Quaker boarding schools in the last years of the $18^{\text {th }}$ century. He showed that the earliest known sampler that followed the 'rule' was produced by a girl with ties to Trenton and her father to Burlington. The rule was also applied to other linens such as bed sheets, and two surviving sheets from 1792 were so labeled by the family that owned the Thomas Taylor house (1765) in Georgetown, Burlington County. ${ }^{125}$

\section{The Issue of Plainness and Simplicity}

The Quaker historian Frederick Tolles, in a portion of a chapter entitled "Of the Best Sort but Plain," described a crisis of spirit that many Quakers faced, especially after 1750, as their material prosperity prompted a worldliness to grow within them. He quoted an ironic comment by Peter Kalm that "Although [Quaker women] pretend not to have their clothes made after the latest fashion, or to wear cuffs and be dressed as gaily as others, they strangely enough have their garments made of the finest and costliest materials that can be procured." Tolles then continued, "In domestic architecture the same tendencies were apparent. The brick town houses of the Quakers ... were as large and as comfortable as those of the most fashionable Anglicans." After admitting that there tended to be a certain austereness of some details, and that Quaker houses generally avoided "elaborate pediments, ... Palladian arches, rusticated quoins, and other purely decorative members," he concluded that "Beyond these subtle distinctions, however, there was little observable difference in grandeur and elegance between the homes of Quaker merchants and

\footnotetext{
${ }^{124}$ Ibid.

${ }^{125}$ Ibid., 52.
} 
those of wealthy families of other denominations. There was equally little difference in the interior furnishings." 126

Chiarappa had little further to add, beyond noting Joshua Evans' caution against fine houses, and that Quakers should not "build their nests too high."127 Chiarappa argued, however, that a central element of patterned brickwork, especially after mid-century, was that "Weighty Friends struggled to find forms that were socially affiliative, yet indicative of their community standing, even while the class separation between the prosperous and the less well-off continued to grow, "in an emergent process of class formation." ${ }^{128}$ Still more recent scholarship has emphasized that the challenge for Quakers was "not so much [a fear of] living in the world but of how people [should] properly [live] in the world."129

Only about a dozen of the several dozen Friends' meetinghouses exhibited patterned brickwork at all, and in each one the matter was handled in a restrained way. Diamonds and zigzags were avoided, as were more elaborate motifs. Flemish checker was the only diaper employed, and that appeared in the very first meetinghouse in Burlington, built 1685-92. Its use in such a conspicuous and respected building must have given implicit permission to Quakers to construct their private buildings in a similar fashion, even in buildings of modest inventiveness, such as that of Christopher White in 1690. The Upper Springfield Friends Meeting was built in 1727 with a Flemish checker façade, but when the Lower Springfield (aka "Copenny”) Friends Meeting (1775) was added, it had only the date in the gable. Evidently the Trenton Friends Meeting House, of 1739-40, was built with both Flemish checker and the date in the gable. The Rancocas Friends

\footnotetext{
126 Tolles, Meeting House and Counting House, 127-128.

${ }^{127}$ Chiarappa, dissertation, 254.

${ }^{128}$ Ibid., 259.

${ }^{129}$ Despite a shift in emphasis between Chiarappa and Herman, there appears to be a broad harmony in their respective interpretations; cf. Chiarappa, dissertation, esp. chaps. 1,2, and 5, and Bernard L. Herman, "Eighteenth-Century Quaker Houses..." in Emma J. Lapsansky, et al. eds., Quaker Aesthetics... (Philadelphia: University of Pennsylvania Press, 2003) 188-211.
} 
Meeting House (1772) exhibits both a Flemish checker façade and the date in the gable end, while the Salem Friends Meeting House (1772), features only the date and underlining beneath it. After Salem, meeting houses limited their expression to dates only where there was any patterned brickwork at all, including the Pilesgrove Friends Meeting House (1785) at Woodstown, and the Moorestown Friends Meeting House (1802).

The Chesterfield Friends Meetinghouse at Crosswicks, built in 1773, reached what appears to have been a unique result. The building includes a datestone, while the walls display a clear dichotomy: Flemish bond executed in plain brickwork on the long south elevation, and Flemish checker on the long north side, carried out with black headers, that appear muted from a distance, not being reflected by direct sunlight. The undeviating manner in which this arrangement was executed implies that it was intentional, the product of a deliberate selection, since it could never have occurred purely by chance. It could be argued that the south side is the building's façade elevation, but there is such a near equivalence between the south and the north sides that it would appear no odium was being cast on either brickwork treatment. One might speculate about how this choice reflected a need to be plain, or how it responded to differences within the meeting's membership, or even whether the north side was considered a second façade, but this feature has been an overlooked element of this building's architectural significance. ${ }^{130}$ No other Friends meeting house built afterward featured Flemish checker.

As for private buildings, published Quaker disciplines included pages that expounded the ideas of plainness and simplicity where personal dress was concerned, but stated almost nothing with respect to architecture or building construction. But there are ways in which notions of simplicity still seem evident in southern New Jersey patterned brickwork. These buildings did not

\footnotetext{
${ }^{130}$ Local historian George DeCou mentioned this feature in passing; see DeCou, Historical Sketches of Crosswicks and Neighborhood (Burlington, NJ: Burlington County Historical Society, 1955), 11.
} 
apply the entire range of enhancements that were sometimes embodied in brick buildings in the Chesapeake, for example. Only a handful of New Jersey patterned brickwork houses included rubbed and gauged brickwork, and then limited to splayed jack arches over windows or doors, but the incidence of this work seems far less than in Maryland or Virginia. Likewise New Jersey's patterned brickwork buildings did not embody even more ambitious and three-dimensional elements such as frontispieces with projecting pilasters and pediments. ${ }^{131}$ New Jersey house builders also seem to have rarely resorted to the further decorative use of washes on the finished brickwork, or of "penciling," the decorative painting of the mortar joints. ${ }^{132}$ These treatments would likely have been beyond the means of most Quaker clients anyway, but would have also struck them as unnecessary and vain.

\section{Patterned Brickwork and the Georgian Style}

As the Georgian style arose in the second quarter of the $18^{\text {th }}$ century, it posed a challenge to patterned brickwork. Prestigious architecture in Britain had already left patterned brickwork behind more than a century before, and the succeeding century of British architecture did not reverse that outcome. Patterned brickwork had persisted in the vernacular realm, from which it spread to the American colonies, but as American builders slowly gained the skills and the wherewithal to build on a grander scale, they understandably looked toward better British work, and the incidence of patterned brickwork in the Delaware Valley lessened, its inventive spirit greatly diminished. Some architectural historians have suggested that patterned brickwork was much more popular before mid-century than afterward. Gabrielle Lanier and Bernard Herman came to that conclusion in their 1997 book Everyday Architecture of the Mid-Atlantic. In their study of Port Penn, Delaware, they found that brick houses that embodied patterned brickwork

\footnotetext{
${ }^{131}$ Cf. for example, Carson et al., The Chesapeake House, 249-250, 252.

132 Ibid., 251.
} 
tended to have been built before 1750, although they were dealing with a small sample size. They explicitly linked this change to the rise of the Georgian style, which came relatively late to this part of the Delaware Valley. "Not until the 1760s did the local builders commissioning new mansion houses begin to embrace the various Georgian plans, and when they did they quickly moved away from visually distinctive local detailing. Windsor, built ... in the 1760 s, abandoned the glazed header brickwork, pent eaves, and cove cornice...."133

Lanier's findings are consistent with others. Robert F. Looney's Old Philadelphia in Early Photographs ... ${ }^{134}$ yields a similar impression, even though it is worth noting that two important Philadelphia buildings, Carpenter's Hall and the Free Quaker Meeting House, built in 1770 and 1789 respectively, both had facades of Flemish checker. In New Jersey, Princeton was one area in which Quakers settled in the 1690s, and where patterned brickwork could have emerged but did not. Its early masonry buildings were constructed of local stone, and when brick was adopted for new buildings beginning in the 1750s — even though the impetus was coming from Philadelphiathose buildings embodied only plain brickwork. ${ }^{135}$

\section{The Federal Style and the Waning of Patterned Brickwork}

In the 1780s, with the ending of the Revolutionary War, the Georgian style in New Jersey began to yield to the Federal style. As the Federal style rose, transitional buildings were increasingly seen that simultaneously introduced elements of the new style while holding onto features of the old. Patterned brickwork fell into the latter category. The transformation took about a decade or longer to complete, and even in the 1790s, especially in rural areas, it was still

\footnotetext{
${ }^{133}$ Gabrielle Lanier and Bernard L. Herman, Everyday Architecture of the Mid-Atlantic: Looking at Buildings and Landscapes (Baltimore: Johns Hopkins University Press, 1997), 287.

${ }_{134}$ Robert F. Looney, Old Philadelphia in Early Photographs, 1839-1914 (New York: Dover Publications, 1976).

${ }^{135}$ Cf. Constance M. Greiff, et al, Princeton Architecture: A Pictorial History of Town and Campus (Princeton, NJ: Princeton University Press, 1967); and Robert W. Craig, The Princeton Architectural Survey (Princeton, NJ: Princeton Joint Historic Sites Commission, 1981), 63-64. The brickwork of some houses is covered in paint or stucco, but none display patterned brickwork, and it has not been reported there.
} 
possible to find new houses rising that could still be called Georgian in their features. Unlike Georgian, however, which conveyed a heavier solidity, the Federal style was a style of subtle effects, led on the exterior by decorative millwork. It could accommodate dates and initials in vitrified headers, since they were placed out of the way in any case, and even here and there a diamond in a gable, but it could not abide diapering, and was incompatible even with Flemish checker, which was a façade treatment. The visual impact of Flemish checker and other brick decoration could be quite strong, especially in favorable lighting conditions. This would take away attention from the elements of the Federal style that embodied the greatest investment of time and attention: the attenuated pieces of carefully fretted woodwork that gave the Federal style its lightness and refinement, delivering the delicate elegance that popularized the style. By the early to middle 1790s, with the completion of such buildings as the New Jersey Statehouse in 1792-94 and the new Burlington County Courthouse in 1796, the Federal style became fully ascendant in New Jersey, and any Georgian buildings constructed after that point were simply retardataire.

Patterned brickwork continued strongly through the 1780s, then seemed to disappear from new construction by the mid-1790s. Of course, one by one, the various types of patterned brickwork designs had been disappearing during the Georgian period, as noted above. This process had started with the diamond diaper, last used in 1746, which had never spread beyond Salem and Cumberland counties. The zig-zags never really caught on, despite the example of the William Hancock house. The exceptional designs of the Dickinson (1754) and Samuel Bassett (1757) houses were last seen in the Samuel Swing house (1775). Banding was the last relatively new decoration introduced, with a brief vogue in the 1780 s, but it, too, was incompatible with the Federal style and it last appeared in a new house in the early 1790s. Yet what really made manifest the end of patterned brickwork was the discontinuance of Flemish checker, which also occurred in 
the early 1790s. ${ }^{136}$ It was the earliest of the diaper treatments, the longest lasting, and the most popular.

Numerals, sometimes with initials, were the last patterned work to be discontinued. They continued to have a functional purpose, especially as dates of construction. The Mayhew house (1792) was the last one in Salem County, the Abbot-Decou house (1797) the last in Mercer County. ${ }^{137}$ Moorestown (1802) was the last Friends meeting house to place the date in brick in its gable. Dates tended to be executed more simply and they were smaller, both narrower and shorter. The Flemington Academy (1810) in Hunterdon County and the John Smith house (1812) in Morris County is an outlying example of the lingering practice. Among surviving buildings, Burlington County provides the most recent examples. The Hollinshead-Peacock house (1786) in Southampton Township bears the date ' 1812 ' in an addition, while the Prickett house (1821), which was surviving in the same township in 1976, is yet to have its current status confirmed.

\section{Disappearance under Stucco (and Paint)}

There was some use of plaster coatings of buildings in the Federal period, and rising interest in the second quarter of the $19^{\text {th }}$ century. At least a few publications appeared, promoting stucco, a cement-based, smooth plaster coating for building exteriors. As used here, however, "stucco" means any lime-sand or lime-sand-cement coating over a previous finish treatment placed upon the exterior of a frame or masonry wall. As patterned brickwork became increasingly oldfashioned, some building owners resorted to stucco as an inexpensive means to freshen up a building whose age or condition, or the impact of multiple alterations, made its appearance less than appealing. This evidently was the cause in 1840 when the Trenton Friends Meeting House,

\footnotetext{
136 The Flemington Academy, built in 1810, embodies Flemish checker in its façade, a lonely chronological outlier.

137 This author has a clear recollection of a Mercer County farmhouse having borne the date '1819' in its gable, but does not recall the precise identity or location, not having seen it since the 1960s. That house was probably lost for a housing development.
} 
built in 1739-40, reached its centennial. ${ }^{138}$ Looking back on these changes in 1872, which included enlarging and stuccoing the building, one man recalled the blue headers that characterized the building before these changes. ${ }^{139}$ Many other buildings followed with like treatment. ${ }^{140}$ Some patterned brickwork was covered under paint, rather than stucco, but paint can be just as effective a hider of vitrified headers.

Both the painted and the stuccoed can be grouped together for purpose of analysis. More than 90 buildings in the patterned brickwork database have been found to be stuccoed or painted, nearly 25 percent of the total. Of these, at least 36 buildings, or about 40 percent, have already had the presence of patterned brickwork confirmed. This may have happened for any of several reasons. Sometimes the stucco or paint was never applied intending to fully obscure all of the patterned brickwork, leaving dates and initials exposed. In several instances, such as the Thomas Buchanan Read house in Bordentown, built about 1765, an owner in recent years has physically removed the stucco. In still other cases, the stucco has been failing, thereby revealing the patterned work beneath. This can happen in two ways, either by spalling, in which the stucco cleanly detaches from the underlying brickwork and falls away, or by a slow, steady erosion of the stucco whereby the underlying pattern slowly emerges. The Ezekiel Wright house in Smithville, Burlington County, is an unusual example where both types of failure are occurring at the same time. As this happens, a date is slowly being revealed.

The other 60 percent of these buildings (about 50) are included in the database provisionally, because while patterned brickwork is strongly suspected there, its actual presence

\footnotetext{
138 A record of the 1840 changes to the Trenton Friends meeting house, including the stuccoing, is found in Philadelphia Yearly Meeting Records, RG2, at Friends Historical Library, Swarthmore College, Swarthmore, PA.

${ }^{139}$ Statement of Isaac Stephens, $8^{\text {th }}$ month 13th, 1872, recalling that the meeting house displayed blue headers in the date and in the wall construction; see Friends Intelligencer 29, 26 (1872) 406-407.

140 This period was one in which many buildings in New Jersey were given a coat of pebble dash, in which small pebbles formed the aggregate.
} 
has not yet been confirmed. Success has followed some of these provisional entries, from a fuller physical inspection of the buildings or by the stucco's failure or removal. In several other cases, however, in which determination was reached that a building does not possess patterned brickwork, that entry has been removed from the database. Occasionally, discovery of patterned brickwork is made in buildings not even suspected. One was the Garwood House on Market Street in Salem City, a Victorian-era hotel that was enlarged from a tavern probably built in the 1750s, with a Flemish checker facade. This building was architecturally investigated in 2002 and extensively repaired — then re-stuccoed!

The importance of further stucco removal lies in the patterned work that is yet to be found. It is highly likely that several more diamond diapers and diamond matrices will be found, giving a more rounded knowledge of how these expansive decorations, especially in Salem County, began. New variations on the zig-zag may be discovered, or a wider range of dates expressed in vitrified brick. Perhaps new unique designs, like the coronets, will be found, and evidence within them that might help identify the tradesmen who produced them. And it should not be thought far-fetched that remote sensing technology might one day produce a method to peer through undisturbed stucco to find the patterned brickwork that lies behind.

\section{The End of Traditional Patterned Brickwork}

The practice of traditional patterned brickwork evidently did not survive the 1830s in New Jersey. The last instance of the placement of a date and initials in a building occurred in Camden County in 1828, while the appearance of a vitrified diamond in at least one Cape May County house evidently occurred during the 1830s. The era of the railroad was beginning, and patterned brickwork found no place in the new architecture that was coming even to Burlington and Salem, the two hearths of this architecture in New Jersey. Both towns had moved on to the Federal style 
as early as the 1790s, for which plain brickwork was a character-defining feature. They also moved on to the Greek Revival style by the 1830s, and produced significant examples of it. Still, however, there gradually arose among some a nostalgic reaction.

In 1858, the Parrish family, owners of a Burlington County estate known as "Oxmead," commissioned a small building to serve as the gatehouse for the property. Although the name of the architect has not been revealed, he was a very apt student of the historic buildings of this region. He designed a small, 1-and-1/2-story house with a gambrel roof like those of Salem County of the 1720s and '30s. He learned all the tricks of the early builders, and produced a marvelous, mannerist masterpiece, completing it with the date "1858" in brick in the end wall facing the road. In this case, however, the headers actually were glazed - a bright black - in a uniformity of size and color that could never have been produced in the $18^{\text {th }}$ century. It was an homage to a vernacular house form already a century out-of-date, actually becoming perhaps the first building in New Jersey to which the label "Colonial Revival" could justifiably apply, and among the earliest in the United States.

When patterned brickwork came back, however — and it did come back ${ }^{141}$ —it could not return in the same way or for the same reasons. Industrialization had come to brickmaking, and the old ways that produced a large percentage of vitrified bricks in each firing were no longer practiced. The clay, itself, may have been little different than before, but the clamps disappeared in favor of kilns that "burned" the brick differently — with convection of hot air rather than a direct flame, and did not cause the glassy surfaces to emerge. This did not happen all at once with every brickmaker, but after about 1850 , as brickmaking machinery replaced craft operations, bricks began to gain a more standard appearance, and were less the result of a person than of a process.

\footnotetext{
${ }^{141}$ Patterned brickwork came back in various guises during the Colonial Revival era.
} 
Where vitrified bricks of the traditional type were still used in mid-19 ${ }^{\text {th }}$-century buildings, they were put in secondary locations where the awkward appearance and random placement of the dark glassy edges did not matter. Within another couple of decades, such bricks disappeared altogether.

Robert W. Craig is a historian and architectural historian who has been active in New Jersey for more than four decades. He supervises New Jersey's participation in the National Register of Historic Places program. He is a member of the Princeton Research Forum, an organization of independent scholars. This is his second article for this journal. 